\title{
COMMENTS
}

\section{AN ECONOMIC ANALYSIS OF THE FAIR USE DEFENSE IN LEIBOVITZ V. PARAMOUNT PICTURES CORPORATION}

\author{
MATTHEW A. EISENSTEIN $^{\dagger}$
}

\begin{abstract}
"Fair use should be perceived not as a disorderly basket of exceptions to the rules of copyright, nor as a departure from the principles governing that body of law, but rather as a rational, integral part of copyright, whose observance is necessary to achieve the objectives of that law."

"Intellectual property is a natural field for economic analysis of law.".
\end{abstract}

\section{INTRODUCTION}

In Leibovitz v. Paramount Pictures Corp., the Court of Appeals for the Second Circuit determined whether the use of a copyrighted photograph of pregnant actress Demi Moore constituted "fair use." ${ }^{3}$ The plaintiff, Annie Leibovitz, is a well-known photographer whose works often depict celebrities in uncommon poses. One of her most recognized works appeared on the cover of the August 1991 issue of the monthly magazine, Vanity Fair. The work depicted the nude, preg-

† B.S. 1997, Northwestern University; J.D. Candidate 2000, University of Pennsylvania. I wish to thank the editors of the University of Pennsylvania Law Review, especially Andrew Morton, Alison Pauly, Felicity Rowe, and Phyllis Staub, for their hard work and assistance. Thanks also to Professors Gorman and Huang for their suggestions on an earlier draft. Special thanks to my parents for their guidance and encouragement, and to Stacey for her constant love and support. Errors are mine alone.

1 Pierre N. Leval, Toward a Fair Use Standard, 103 HARV. L. REv. 1105, 1107 (1990).

2 William M. Landes \& Richard A. Posner, An Economic Analysis of Copyright Law, 18 J. LEGAL STUD. 325, 325 (1989).

${ }^{3}$ See Leibovitz v. Paramount Pictures Corp., 137 F.3d 109, 112 (2d Cir. 1998) (asserting that both sides disagree only as to the availability of the affirmative defense of fair use since there is no dispute over plaintiff's prima facie case of infringement). "The fair use doctrine "permits other people to use copyrighted material without the owner's consent in a reasonable manner for certain purposes." Id. (quoting Rogers v. Koons, 960 F.2d 301, 308 (2d Cir. 1992)). 
nant body of actress Demi Moore, in profile, with her right arm covering her breasts, and her left hand supporting her stomach. ${ }^{4}$ The issue became one of the "best selling issues" of Vanity Fair."

Early in 1994, the defendant, Paramount Pictures, ran an advertising campaign for its upcoming comedy motion picture, Naked Gun 33 1/3: The Final Insult. As part of the campaign, Paramount produced a poster displaying the face of the movie's star, Leslie Nielson, on the nude body of a pregnant woman, with the slogan "DUE THIS MARCH." ${ }^{\text {" }}$ Paramount did not mechanically copy Leibovitz's picture but rather commissioned a photographer to pose a pregnant, nude body, designed to emulate the photograph of Moore." "Great effort was made to ensure that the photograph resembled in meticulous detail the one taken by Leibovitz." ${ }^{8}$ Leibovitz "protested the use" and subsequently brought an action for copyright infringement. ${ }^{9}$

The District Court for the Southern District of New York entered summary judgment for the alleged infringer, Paramount. ${ }^{10}$ Applying both the statutory four-pronged fair use analysis, ${ }^{11}$ and the Supreme Court's recent analysis in Campbell v. Acuff-Rose Music, Inc., ${ }^{12}$ the district court held that use of Leibovitz's photograph by Paramount was fair. ${ }^{13}$ Leibovitz appealed, contending that even if the advertisement was ap-

${ }_{5}^{4}$ See Leibovitz, 137 F.3d at 111 (detailing the image).

${ }^{5} I d$.

${ }^{6} I d$.

7 See id. (describing the process by which the photograph's concept was developed and executed).

${ }^{8} I d$.

${ }^{9} I d$. at 112.

${ }^{10}$ See Leibovitz v. Paramount Pictures Corp., 948 F. Supp. 1214, 1226 (S.D.N.Y. 1996).

II The relevant part of the statute states:

In determining whether the use made of a work in any particular case is a fair use the factors to be considered shall include-(1) the purpose and character of the use ...; (2) the nature of the copyrighted work; (3) the amount and substantiality of the portion used in relation to the copyrighted work as a whole; and (4) the effect of the use upon the potential market for or value of the copyrighted work.

17 U.S.C. $\$ 107$ (1994).

${ }_{12} 510$ U.S. 569, 578-94 (1994).

1s See Leibovitz, 948 F. Supp. at 1226. The district court found that "[t]hree of the four fair use factors in the present case militate in favor of a finding of fair use, largely because the defendant's transformation of the plaintiff's photograph has resulted in public access to two distinct works ...." Id. Furthermore, Leibovitz stated in her deposition that she thought the Nielsen picture was a parody of her own, and the court subsequently found that the Nielsen photograph was parody rather than satire. See id. at 1222-23. 
propriately considered a parody of her photograph, Paramount used the work for "commercial purposes" and utilized more than necessary for the parody. ${ }^{14}$ Leibovitz thus claimed "that the District Court erred in granting Paramount's motion for summary judgment. ${ }^{\text {15 }}$ The Second Circuit affirmed, however, holding that Paramount Picture's advertisement of the forthcoming movie was a fair use of the plaintiff's work. ${ }^{16}$ Like the district court, the appellate court based its reasoning on the four statutory factors defining fair use and the Supreme Court's analysis in Campbell, in which the Court addressed the fair use defense for works of parody. ${ }^{17}$

This Comment will demonstrate that lower courts have struggled with the fair use defense, especially for works of parody, and continue to struggle even after the Supreme Court's decision in Campbell. An economic approach will provide a useful framework for analyzing this doctrine. Part I provides an overview of the fair use defense, focusing on parody as a fair use and revealing the difficulties that lower courts have encountered in dealing with the issue. I then discuss the Campbell decision and the uncertainty authors and parodists may continue to face. In addition, Part I explains the benefits of an economic approach to a fair use analysis. Part II describes basic economic princi-

${ }^{14}$ Leibovitz, 137 F.3d at 112 .

${ }^{15}$ Id.

${ }^{16}$ See id. at 110 (stating that although the advertisement had a commercial use, it qualified as a parody and was entitled to the fair use defense).

${ }^{17}$ See Campbell, 510 U.S. at 575-91 (stating that under $\$ 107$ and common law traditions, one may use copyrighted material to parody, comment, or criticize); see also Leibovits, 137 F.3d at 112-14 (discussing the Campbell Court's clarification of the fair use defense). The Court in Campbell clarified the fair use defense for all works by requiring a consideration of the four statutory fair use factors without any presumptive weight given to any single factor. See id. at 113 (acknowledging that the Court changed its position to "an aggregate weighing of all four fair use factors"). The Court specifically abandoned the dicta in Somy Corp. of America v. Universal Cily Siudios, Inc., 464 U.S. 417,451 (1984), by stating that "every commercial use of copyrighted material is presumptively... unfair...." Campbell, 510 U.S. at 584. The Court also departed from its previous view that the fourth factor, the effect of the use upon the potential market for the copyrighted work, was the most important factor to be considered, by stating that "the importance of this factor will vary ... . with the relative strength of the showing on the other factors." Id. at 590 n.21.

Parody has been defined as "the art of creating a new literary, musical, or other artistic work that both mimics and renders ludicrous the style and thought of an original." Acuff-Rose Music, Inc. v. Campbell, 972 F.2d 1429, 1441 n.4 (6th Cir. 1992), rev'd, 510 U.S. 569 (1994) (Nelson, J., dissenting) (citing Note, The Parody Defense to Copyright Infringement: Productive Fair Use After Betamax, 97 HARV. L. REV. 1395, 1395 (1984)); see also infra note 82 (stating the Supreme Court's definition of parody for copyright cases); infra text accompanying notes 149-51 (defining parody for an economic purpose). 
ples and applies them to relevant aspects of copyright law. I then propose an economic model based on a survey of existing scholarly models to evaluate parody in fair use and discuss the limitations of the model. Finally, Part III explains the Second Circuit's decision in Leibovitz and explores whether the decision is consistent with the economic model. The Comment closes with the conclusion that the Second Circuit's decision is not consistent with the results reached by an economic approach to the fair use defense for works of parody.

\section{BACKGROUND}

\section{A. An Overview of Derivative Works and the Fair Use Doctrine}

The Constitution grants Congress the power to "[p]romote the Progress of Science and the useful Arts, by securing for limited Times to Authors ... the exclusive Right to their respective Writings." ${ }^{18}$ The dual aims of copyright law are to stimulate creativity and to disseminate knowledge in order to enrich culture and foster the growth of learning for the public welfare. ${ }^{19}$ Since 1790 , Congress has passed a number of copyright statutes to meet these ends. ${ }^{20}$ To stimulate creativity, copyright law provides personal economic incentives by granting an author exclusive control over an original, expressive work. ${ }^{21}$ Such exclusive control, however, is limited in time to ensure the dissemination of such intellectual works into the public domain. ${ }^{22}$ Thus, the law

${ }^{18}$ U.S. CONST. art. I, $\$ 8$, cl. 8.

${ }^{19}$ See Twentieth Century Music Corp. v. Aiken, 422 U.S. 151, 156 (1975) ("The immediate effect of our copyright law is to secure a fair return for an 'author's' creative labor. But the ultimate aim is, by this incentive, to stimulate artistic creativity for the general public good.").

${ }^{20}$ For a general historical perspective of copyright law, see ROBERT A. GORMAN \& JANE C. GINSBURG, COPYRIGHT I-12 (5th ed. 1999).

${ }^{21}$ The economic philosophy behind the clause empowering

Congress to grant patents and copyrights is the conviction that encouragement of individual effort by personal gain is the best way to advance public welfare through the talents of authors and inventors in "Science and useful Arts." Sacrificial days devoted to such creative activities deserve rewards commensurate with services rendered.

Mazer v. Stein, 347 U.S. 201, 219 (1954). But see Feist Publications, Inc. v. Rural Tel. Serv. Co., 499 U.S. 340, 344-51 (1991) (determining that the ultimate goal of copyright law is to encourage the production of new works and not necessarily to compensate the author of such works).

${ }_{22}$ As stated by the legislative report on the Copyright Act of 1909:

In enacting a copyright law Congress must consider ... two questions: First, how much will the legislation stimulate the producer and so benefit the public, and, second, how much will the monopoly granted be detrimental to the 
balances the creative incentives to an author by granting a monopoly, with the proper public access to those works by limiting the time of the monopoly status. ${ }^{23}$

An author usually receives adequate economic incentives to create original works and share them with the public since a copyright monopoly grants exclusive control of the rights to reproduce, distribute, and display a work. ${ }^{24}$ The copyright monopoly may stifle creativity in

public? The granting of such exclusive rights, under the proper terms and conditions, confers a benefit upon the public that outweighs the evils of the temporary monopoly.

H. REP. No. 60-2222, at 7 (1909). The Supreme Court has recognized that in the limited grant "an important public purpose may be achieved. It is intended to motivate the creative activity of authors and inventors by the provision of a special reward, and to allow the public access to the products of their genius after the limited period of exclusive control has expired." Sony, 464 U.S. at 429.

Under the 1909 Copyright Act, copyright protection lasts for a term of 28 years from the date of publication, though it may be renewed for an additional term of 28 years. See 17 U.S.C. $\$ \S 302(a), 304$ (a) (1994) (stating length of copyright protection). Under the 1976 Copyright Act, works created after January 1, 1978 are protected for the life of the author plus seventy years from the author's death. See id.

${ }^{23}$ See Landes \& Posner, supra note 2, at 326 ("Striking the correct balance between access and incentives is the central problem in copyright law."). Judicially created copyright doctrines attempt to achieve a balance between monopoly and access. See Leval, supra note 1, at 1109 \& nn.22-23 (discussing the three judicially created copyright doctrines addressing this balance). First, copyright law extends only to expression, not to ideas or facts. See 17 U.S.C. $\$ \S 102(a), 102$ (b) (1994) (copyright protection extends to "original works of authorship fixed in any tangible medium of expression, " but not to "idea[s]" or concepts); Baker v. Selden, 101 U.S. 99, 107 (1879) (holding that copyright of the expression of an idea does not grant a copyright in the underlying idea or system). Second, facts are not within the copyright protection. See Feish 499 U.S. at 347 ("The distinction is one between creation and discovery: The first person to find and report a particular fact has not created the fact; he or she has merely discovered its existence."). Finally, the fair use doctrine protects access to certain works that would otherwise be infringements. See infra text accompanying notes 37-38 (describing the purpose of the fair use defense).

${ }^{24}$ SeeWendy J. Gordon, Fair Use as Market Failure: A Siructural and Economic Analysis of the Betamax Case and Its Predecessors, 82 ColUM. L. REv. 1600, 1601 (1982) (determining that the dual aims of copyright-financial incentive to authors and promotion of science and the useful arts-rarely conflict because authors are given adequate compensation for their efforts); see also 17 U.S.C. $\$ 106$ (1994). Section 106 states that an author has the exclusive rights:

(1) to reproduce the copyrighted work in copies or phonorecords; (2) to prepare derivative works based upon the copyrighted work; (3) to distribute copies or phonorecords of the copyrighted work to the public by sale or other transfer of ownership, or by rental, lease, or lending; (4) in the case of literary, musical, dramatic, and choreographic works, pantomimes, and motion pictures and other audiovisual works, to perform the copyrighted work publicly; and (5) in the case of literary, musical, dramatic and choreographic works, pantomimes, and pictorial, graphic, or sculptural works, including the 
certain circumstances since it also extends to the author the right to prepare derivative works. ${ }^{25}$ This might discourage a second author from building upon the work of the original author during the existence of the original copyright.

A derivative work transforms or adapts one or more preexisting works such that the product constitutes an original work of authorship. ${ }^{26}$ A derivative work may be a translation of a book or, as in Leibovitx, a movie poster based on the cover of a magazine. Copyright protection in derivative works extends only for those original elements contributed by the derivative author. ${ }^{27}$ As such, a derivative copyright in no way affects the copyright in the underlying work, which rests entirely with the author of that work. ${ }^{28}$ Although the amount of contribution necessary to reach the threshold of originality is somewhat ambiguous, ${ }^{29}$ courts generally agree that derivative works require more than trivial adaptations to original works to warrant copyright protection. $^{30}$

The problem of providing an author with control over derivative works thus becomes evident. Since derivative works necessarily are creative and the dissemination of such works enriches the public domain, society should encourage their creation. Yet, the exclusive right to prepare derivative works rests solely with authors who may refuse to

individual images of a motion picture or other audiovisual work, to display the Id. copyrighted work publicly.

${ }^{25}$ See 17 U.S.C. $\$ 103$ (a) (1994) ("The subject matter of copyright... includes compilations and derivative works ....").

${ }^{26}$ See id. $\$ 101$ (defining derivative works as "work[s] based upon one or more preexisting works").

${ }^{27}$ See id. $\$ 103$ (b) ("The copyright in a ... derivative work extends only to the material contributed by the author of such work, as distinguished from the preexisting material employed in the work....").

${ }^{28}$ See id. ("The copyright in such [derivative] work is independent of . . . any copyright protection in the preexisting material.").

${ }^{29}$ For example, disagreement over adequate separation from the original work has arisen in the context of art and sculptural reproductions. In Gracen v. Bradford Exchange, Judge Posner ruled that a derivative work "must be substantially different from the underlying work to be copyrightable." $698 \mathrm{~F} .2 \mathrm{~d} \mathrm{300,305}$ (7th Gir. 1983). By contrast, in Alva Studios, Inc. $v$. Winninger, the court found that despite an extremely precise level of exactitude, a replica could still possess sufficient originality to warrant copyright protection. 177 F. Supp. 265, 267-68 (S.D.N.Y. 1959).

See, e.g., Feist Publications, Inc. v. Rural Tel. Serv. Co., 499 U.S. 340, 348 (1991) (holding that the Constitution only affords copyright protection to works that possess more than a de minimis amount of creativity); L. Batlin \& Son, Inc. v. Snyder, 536 F.2d 486, 492 (2d Cir. 1976) (en banc) ("To extend copyrightability to miniscule variations would simply put a weapon for harassment in the hands of mischievous copiers intent on appropriating and monopolizing public domain work."). 
allocate such a right. ${ }^{31}$ There are two reasons why the copyright monopoly for derivative works may be overly broad. ${ }^{32}$ First, "all intellectual creative activity is in part derivative" or secondary. ${ }^{33}$ Authors frequently create new works by borrowing or building upon previous works while adding original expression of their own. ${ }^{34}$ Second, fundamental areas of intellectual activity, such as philosophy, criticism, history, and the natural sciences, necessarily require reference to previous works. ${ }^{35}$ Stated another way, "[m] onopoly protection of intellectual property that impede[s] referential analysis and the development of new ideas out of old would strangle the creative process. ${ }^{36}$ As a result, to achieve an adequate enrichment of culture, some leeway must be given to derivative authors to freely utilize previously created and copyrighted works.

To address the excessive protection received by an original author to prepare derivative works, copyright law provides the affirmative defense of fair use, ${ }^{37}$ which permits a defendant's reasonable use of

31 See Michael A. Chagares, Parody or Piracy: The Prolective Scope of the Fair Use Defense to Copyright Infringement Actions Regarding Parodies, 12 COLUM.-VLA J.L. \& ARTS 229, 232 33 (1988) (discussing the fundamental conflict in the law between an author's exclusive right to his work and the fundamental goal of copyright "to encourage creative endeavors and their dissemination throughout society").

${ }^{32}$ See Gordon, supra note 24, at 1602 (asserting that the primary goal of copyright is promotion of the useful arts and sciences, and that when a conflict exists between this goal and the author's right to monopoly protection, the author's right must "give way before a social need for access"); Leval, supra note 1, at 1109 ("Notwithstanding the need for monopoly protection of intellectual creators to stimulate creativity and authorship, excessively broad protection would stifle, rather than advance, the objective.").

${ }^{33}$ Leval, supra note 1 , at 1109.

\$4 See Campbell v. Acuff-Rose Music, Inc., 510 U.S. 569, 575 (1994) ("Every book in literature, science and art, borrows, and must necessarily borrow, and use much which was well known and used before." (citing Emerson v. Davies, 8 F. Cas. 615, 619 (C.C.D. Mass. 1845) (No. 4,436))).

${ }^{35}$ See7 U.S.C. § 107 (1994) (enumerating fundamental intellectual pursuits requiring reference to previous works).

${ }^{36}$ Leval, supra note 1 , at 1109.

${ }^{37}$ See supra note 3 (defining the fair use doctrine). First Amendment considerations also accompany the public interest in dissemination of derivative works. The Supreme Court has stated that the laws of the Copyright Act sufficiently embrace such First Amendment concerns. See Harper \& Row, Publishers, Inc. v. Nation Enters., 471 U.S. 539, 560 (1985) (noting that First Amendment rights are embodied in the Copyright Act's identification of copyrightable expressions). Indeed, courts have rejected challenges to copyright infringement based on First Amendment arguments. See, e.g., Nihon Keizai Shimbun, Inc. v. Comline Bus. Data, Inc., 166 F.3d 65, 74 (2d Cir. 1999) ("We have repeatedly rejected First Amendment challenges to injunctions from copyright infringement on the ground that First Amendment concerns are protected by and coextensive with the fair use doctrine."). 
copyrighted material without an author's consent. Fair use provides the public, and subsequent authors, with socially desirable access to intellectual works while maintaining an author's incentive to create by respecting the author's right to control derivative uses of his creation. $^{38}$ Generally speaking, in Leibovitz, the fair use inquiry weighed both the social benefit derived from Paramount's use of Leibovitz's photograph and the proper reward and incentive for her creativity. Of course, evaluating such a delicate balance has never been easy; a panel of three judges that included Judge Learned Hand once described the fair use doctrine as "the most troublesome in the whole law of copyright. ${ }^{39}$

As a judicially created doctrine, the oft-cited words of Justice Story guided common law adjudication of fair use:

[W] must often, in deciding questions of this sort, look to the nature and objects of the selections made, the quantity and value of the materials used, and the degree in which the use may prejudice the sale, or diminish the profits, or supersede the objects, of the original work. ${ }^{40}$

Congress, by section 107 of the Copyright Act of 1976, codified Justice Story's language into four statutory factors:

(1) the purpose and character of the use, including whether such use is of a commercial nature or is for nonprofit educational purposes; (2) the nature of the copyrighted work; (3) the amount and substantiality of the portion used in relation to the copyrighted work as a whole; and (4) the effect of the use upon the potential market for or value of the copyrighted work. ${ }^{41}$

Congress, however, realized the importance of the developed case law in codifying the fair use provisions ${ }^{42}$ and, consequently, left the courts with the task of interpreting the four factors. ${ }^{43}$

${ }^{33}$ For other judicially created doctrines that balance access with monopoly, see supra note 23.

39 Dellar v. Samuel Goldwyn, Inc., 104 F.2d 661, 662 (2d Cir. 1939) (per curiam).

${ }^{40}$ Folsom v. Marsh, 9 F. Cas. 342, 348 (C.C.D. Mass. 1841) (No. 4,901).

${ }^{41}$ Copyright Act of $1976 \S 107,17$ U.S.C. $\$ 107$ (1994). For a more detailed description of the Supreme Court's analysis of the four factors, see infra text accompanying notes 78-98.

${ }^{42}$ See H.R. REP. NO. 94-1476, at 66 (1976), reprinted in 1976 U.S.C.C.A.N. 5659, 5680 (clarifying that the congressional intent in $\$ 107$ is to "restate the present judicial doctrine of fair use, not to change, narrow, or enlarge it in any way").

${ }^{43}$ In a fair use analysis, courts are permitted "to avoid rigid application of the copyright statute when, on occasion, it would stifle the very creativity which that law is designed to foster." Iowa State Univ. Research Found. Inc. v. American Broad. Co., 621 F.2d 57, 60 (2d Cir. 1980). 


\section{B. Parody as Fair Use}

\section{Pre-Campbell Developments}

Parody has been recognized as an independent and important art form for centuries. ${ }^{44}$ Defined as "a literary or musical work in which the style of an author or work is closely imitated for comic effect or in ridicule, ${ }^{, 45}$ a parody is a method of comment and criticism that humorously imitates an underlying work by focusing on its weaknesses. ${ }^{46}$ A successful parody requires taking a sufficient amount of expression from an underlying work to recognize, or "conjure up" the original. ${ }^{47}$ As a result, an author might sue a parodist who could be infringing on the author's exclusive right to prepare a derivative work. ${ }^{48}$

To make a prima facie case for copyright infringement, a plaintiff must prove: "(1) ownership of a valid copyright, and (2) copying of constituent elements of the work that are original." ${ }^{49}$ Assuming that the first element is met, ${ }^{50}$ the second element may be satisfied by showing direct evidence that the defendant copied the material, or by showing both that the defendant had "access to the plaintiff's copyrighted work" and that the "defendant's work is substantially similar to the plaintiff's copyrightable material. ${ }^{, 51}$ Thus, to avoid a suit for infringement, a parodist who takes material for a derivative work first must secure the consent of the original author. ${ }^{52}$ Courts, however, will

${ }^{44}$ For a general historical account of parody and copyright law, see Yankwich, 33 CAN. B. REV. 1130, 1133-37 (1995).

${ }^{45}$ WEBSTER'S NINTH NEW COLlegIate DictionaRY 857 (9th ed. 1989).

${ }^{16}$ See supra note 17 (defining parody); infra note 82 (stating the Supreme Court's definition of parody for copyright cases).

${ }^{47}$ See Dr. Seuss Enters. v. Penguin Books USA, Inc., 109 F.3d 1394, 1400 (9th Gir. 1997) (adopting a test where "the parodist is permitted a fair use of a copyrighted work if it takes no more than is necessary to 'recall' or 'conjure up' the object of his parody").

See Alfred C. Yen, When Authors Won't Sell: Parody, Fair Use, and Efficiency in Copyright Law, 62 U. COLO. L. REv. 79, 86 (1991) ("[I]t is clear that parodies infringe the author's right to control creation of 'derivative works.' Since parodies always borrow and recast the plot, words, and style of a preexisting original, they necessarily fall under the definition of derivative work.").

${ }^{49}$ Feist Publications, Inc. v. Rural Tel. Serv. Co., 499 U.S. 340, 361 (1991).

${ }^{50}$ A certificate of registration constitutes prima facie evidence of the validity of a copyright. See 17 U.S.C. $\$ 410$ (c) (1994) ("In any judicial proceedings the certificate of a registration ... shall constitute prima facie evidence of the validity of the copyright ...."); Folio Impressions, Inc. v. Byer Cal., 937 F.2d 759, 763 (2d Cir. 1991) (noting that the presumption of validity may be rebutted).

${ }^{51}$ Computer Assocs. Int'l, Inc. v. Altai, Inc., 982 F.2d 693, 701 (2d Cir. 1992).

52 See supra notes 25-28 and accompanying text (explaining that the right to pre- 
construe section 107 of the 1976 Copyright Act to permit a fair use defense for works of parody, ${ }^{53}$ as such works "are valued forms of criticism, encouraged because this sort of criticism itself fosters the creativity protected by the copyright law. ${ }^{{ }^{54}}$ Therefore, a defendant who takes a substantive amount of copyrighted material without securing the permission of the owner may defend the parody as a fair use of the original work.

Prior to the Supreme Court decision in Campbell v. Acuff-Rose, in which the Court attempted to clarify the fair use defense for works of parody, an analysis of lower court decisions under section 107 concerning parodies reveals a variety of inconsistencies. ${ }^{55}$ Under the first factor, the purpose and the nature of the parody, courts differed in their reactions to a parodist's commercial motive. Some courts, such as the Second Gircuit, simply presumed that any commercial motive weighed against fair use. ${ }^{56}$ Courts such as the Ninth Circuit also presumed that a commercial purpose weighed against fair use, but permitted the defendant to rebut this presumption by convincing the court that the parody did not "unfairly diminish the economic value of the original. ${ }^{, 57}$ One court even refused to consider the commercial

pare a derivative work rests with the original author).

${ }^{53}$ Typical fair uses listed in the statute include the use of copyrighted works for "criticism, comment, news reporting, teaching, ... .scholarship, or research." 17 U.S.C. $\$ 107$ (1994). However, "types of uses beyond the six enumerated in the preamble to section 107 may also be considered. Parody is a common example of such a use." H.R. REP. No. 102-836, at 3 n.6 (1992); see also Dr. Seuss Enters. v. Penguin Books USA, Inc., 109 F.3d 1394, 1400 (9th Cir. 1997) (applying $\$ 107$, the court determined that "[p]arody is regarded as a form of social and literary criticism, having a socially significant value").

${ }_{55}^{54}$ Rogers v. Koons, 960 F.2d 301, 310 (2d Cir. 1992).

55 See Campbell v. Acuff-Rose Music, Inc., 510 U.S. 569, 575 (1994) (articulating the four main factors of a fair use inquiry); Lisa M. Babiskin, Oh, Pretty Parody: Campbell v. Acuff-Rose Music, Inc., 8 HARV. J.L. \& TECH. 193, 196 (1994) (noting that lower courts have "produced an inconsistent and confusing body of case law"); Anatasia P. Winslow, Rapping on a Revolving Door: An Economic Analysis of Parody and Campbell v. Acuff-Rose Music, Inc., 69 S. CAL. L. REV. 767, 788-91 (1996) (providing examples of inconsistencies in lower court decisions prior to Campbell).

${ }^{56}$ See, e.g., MCA, Inc. v. Wilson, 677 F.2d 180, 182 (2d Cir. 1981) ("While commercial motivation and fair use can exist side by side, the court may consider whether the alleged infringing use was primarily for public benefit or for private commercial gain."); Tin Pan Apple, Inc. v. Miller Brewing Co., 737 F. Supp. 826, 832 (S.D.N.Y. 1990) (determining that defendant's commercial purpose alone prevented a finding of fair use).

${ }^{57}$ Fisher v. Dees, 794 F.2d 432, 437 (9th Cir. 1986) (presuming that a commercial motive would weigh against a finding of fair use, but allowing the presumption to be rebutted by a showing that the parody's true purpose is social commentary). 
motive in its analysis. ${ }^{58}$

In determining whether a work constituted a parody, courts typically would assess whether it contained direct commentary on the original work or rather a commentary on society at large. Courts often held that humorous or satirical work gained protection under the fair use doctrine only if the copied work was the target of the work in question. $^{59}$ Otherwise, the reasoning suggests, there would be no need to "conjure up" the original in an audience's mind, and there would be no justification for borrowing from it. ${ }^{60}$ For example, in Fisher v. Dees, the Ninth Circuit found that the defendant's song, "When Sonny Sniffs Glue," successfully constituted fair use parody because the song clearly poked fun at the original Johnny Mathis song "When Sunny Gets Blue." ${ }^{\text {"11 }}$ Other courts, however, determined that a defendant's work did not need specifically to parody the plaintiff's material to find a fair use. For example, in Elsmere Music, Inc. v. National Broadcasting Co., the District Court for the Southern District of New York held that "[ $t$ ]o the extent that [other cases] can be read to require that there be an identity between the song copied and the subject of the parody, this Court disagrees. ${ }^{, 62}$

One court refused to consider all the fair use factors after determining that the work at issue was not a parody. In Tin Pan Apple, Inc. v. Miller Brewing Co., the District Court for the Southern District of New York found that a beer commercial with actors imitating the rap group "The Fat Boys" did not qualify as a parody because it did not contribute "something new for humorous effect or commentary. ${ }^{, 63}$ As a result, the advertisement was not entitled to the fair use defense. ${ }^{64}$

${ }^{53}$ See Pillsbury Co. v. Milky Way Prods., Inc., 215 U.S.P.Q. (BNA) 124, 131 (N.D. Ga. 1981) (finding that the defendant's parody, appearing in a magazine, was a social commentary and not a commercial use that weighs against a fair use).

${ }^{59}$ See Fisher, 794 F.2d at 436 (finding fair use when "it was clear... that Dees's version was intended to poke fun at the composers' song, and at Mr. Mathis's rather singular vocal range"); Walt Disney Prods. v. Air Pirates, 581 F.2d 751, 758 n.15 (9th Cir. 1978) (determining that it was not fatal "that the 'Air Pirates' were parodying life and society in addition to parodying the Disney characters").

${ }^{60}$ See MCA, 677 F.2d at 185 (finding that "if the copyrighted song is not at least in part an object of the parody, there is no need to conjure it up").

${ }^{61}$ See Fisher, 794 F.2d at 436 (determining that direct commentary of Dees's song "When Sonny Sniffs Glue" was necessary for a fair use of Johnny Mathis's original song, "When Sunny Gets Blue").

${ }_{62}$ Elsmere Music, Inc. v. NBC, 482 F. Supp. 741, 746 (S.D.N.Y. 1980), affd, 623 F.2d 252 (2d Cir. 1980).

${ }^{6 s}$ Tin Pan Apple, Inc. v. Miller Brewing Co., 737 F. Supp. 826, 832 (S.D.N.Y. 1980) (quoting Elsmere Music, 623 F.2d at 253 n.1).

${ }^{64}$ See id. (refusing to consider the fair use factors since the entirely for-profit adver- 
Inconsistencies among the lower courts also are apparent in analyzing various applications of the third factor of fair use, the substantiality of the taking. Some lower courts held that excessive copying for use in a parody precluded a fair use defense, ${ }^{65}$ while others found that copying an entire work did not preclude a finding of fair use. ${ }^{66}$ Most courts realized, however, that the copying must be substantial enough to "conjure up" the original, ${ }^{67}$ as a parodist must rely heavily on the original work to adequately imitate.

These inconsistencies demonstrate that prior to the Supreme Court's decision in Campbell, the lower courts' application of section 107 to works of parody was in a state of disarray. Although the equitable approach of fair use balances the divergent interests of the original author and the parodist in a case-by-case manner, ${ }^{69}$ the lower courts failed to act consistently in determining what uses should be deemed fair. ${ }^{70}$

tisement did not even qualify as a parody).

${ }^{65}$ See, e.g., Walt Disney Prods.v. Air Pirates, 581 F.2d 751, 758 (9th Cir. 1978) (determining that the defendant's copying of the plaintiff's Disney characters in their entirety was more than "necessary to place firmly in the reader's mind the parodied work and those specific attributes that are to be satirized"); Walt Disney Prods. v. Mature Pictures Corp., 389 F. Supp. 1397, 1398 (S.D.N.Y. 1975) ("[P]ermissible parody of the copyright article is not a complete copy of the original.").

${ }_{66}$ See, e.g., Hustler Magazine, Inc. v. Moral Majority, Inc., 796 F.2d 1148, 1155 (9th Cir. 1986) (asserting that some case law indicates "that the copying of an entire work does not preclude fair use per $\left.s e^{n}\right)$.

${ }_{67}$ See Fisher v. Dees, 794 F.2d 432, 438-39 (9th Cir. 1986) (agreeing with the reasoning of the district court in Elsmere); Elsmere Music, 623 F.2d at $253 \mathrm{n} .1$ ("[T]he concept of 'conjuring up' an original came into the copyright law not as a limitation ... but as a recognition that a parody frequently needs to be more than a fleeting evocation of an original in order to make its humorous point."); Pillsbury Co. v. Milky Way Prods., Inc., 1981 WL 1402, at *10 (N.D. Ga. Dec. 24, 1981) (finding fair use even though the defendant copied more than necessary to "conjure up" the original).

See Julie Bisceglia, Parody and Copyright Protection: Tuming the Balancing Act into a Juggling Act, 34 COPYRIGHT L. SYMP. (ASCAP) 1, 17 (1987) ("Parody by its nature demands close imitation, and any attempt to limit its scope will correspondingly limit the parodist in his craft.").

${ }^{69}$ See Harper \& Row, Publishers, Inc. v. Nation Enters., 471 U.S. 539, 560 (1985) (determining that fair use calls for a case-by-case analysis because it involves a mixed question of fact and law); William F. Patry \& Shira Perlmutter, Fair Use Misconstrued: Profit, Presumptions, and Parody, 11 CARDOZO ARTs \& ENT. L.J. 667, 687 (1993) ("Fair use is a weighing process involving nonexclusive and multifaceted factors, not an exercise in computation.").

${ }^{70}$ See Chagares, supra note 31 , at 235 (determining that as a result of the courts' "application to the facts of the small number of published opinions dealing with the issue of copyright infringement and parody, decisions have been inconsistent and irreconcilable"). 


\section{The Supreme Court's Decision in Campbell v. Acuff-Rose Music, Inc.}

In Campbell, ${ }^{71}$ the Supreme Court determined whether the rap group 2 Live Crew's parody of Roy Orbison's "Oh, Pretty Woman" constituted a fair use. ${ }^{72}$ Although 2 Live Crew offered to pay a fee and recognize Orbison and Dees as the creators, the plaintiff, Acuff-Rose, refused to grant 2 Live Crew permission to use the song. ${ }^{73}$ Despice this refusal, 2 Live Crew created the parody entitled "Pretty Woman," and released the song, giving Orbison, Dees, and Acuff-Rose credit for authoring and publishing the original version. ${ }^{74}$ Acuff-Rose sued for copyright infringement. The district court granted 2 Live Crew's motion for summary judgment. ${ }^{75}$ The Sixth Circuit Court of Appeals reversed, finding that the defendant failed to overcome the presumption that the commercial nature of the song made the use unfair. ${ }^{76}$

The Supreme Court granted certiorari "to determine whether 2 Live Crew's commercial parody could be a fair use." ${ }^{\text {"77 }}$ After providing a brief history of the fair use doctrine, the Court noted that any fair use analysis required a flexible, case-by-case application of the four prongs in section $107 .{ }^{78}$ With the stage set, the Court evaluated 2 Live Crew's song under the four factors.

Under the first factor, the purpose and character of the use, the Court stated that the inquiry should focus on "whether the new work

71510 U.S. 569 (1994).

${ }^{2}$ See id. at 574 (asserting that "2 Live Crew's song would be an infringement of Acuff-Rose's rights in 'Oh, Pretty Woman,' under the Copyright Act of 1976 . . . but for a finding of fair use through a parody").

${ }^{73}$ See id. at 572-73 (describing 2 Live Crew's manager's offer to "afford all credit for ownership and authorship of the original song to Acuff-Rose, Dees, and Orbison" and Acuff-Rose's agent's response letter, which stated, "I am aware of the success enjoyed by "The 2 Live Crews", but I must inform you that we cannot permit the use').

${ }^{74}$ See id. at 573 .

75 See Acuff-Rose Music, Inc. v. Campbell, 754 F. Supp. 1150 (M.D. Tenn. 1991), rev'd, 972 F.2d 1429 (6th Cir. 1992), rev'd, 510 U.S. 569 (1994). The district court applied the four statutory factors of $\$ 107$ and found that the commercial nature of the parody did not make it presumptively unfair. See id. at 1154. The district court also found that 2 Live Crew "appropriate[d] no more from the original than is necessary to accomplish reasonably its parodic purpose." Id. at 1157. As to the fourth factor, the court found that the parody likely would not have a negative impact on the market for the plaintiff's song. See id.

${ }^{76}$ See Campbell, 972 F.2d at 1439 (presuming and holding that use of the song was unfair due to the commercial nature of the use).

77 510 U.S. at 574.

${ }^{78}$ See id. at 577 (stating that " $[\mathrm{t}]$ he task is not to be simplified with bright-line rules, for the statute, like the doctrine it recognizes, calls for case-by-case analysis"). 
merely 'supersede[s] the objects' of the original creation ... or instead adds something new, with a further purpose or different character. ... [I]t asks, in other words, whether and to what extent the new work is 'transformative." "'79 Encouraging transformative creations, the Court reasoned, furthers the goal of copyright-to promote the sciences and useful arts. ${ }^{80}$ The Court found that parodies possess transformative value because they provide "social benefit."si Thus, the Court firmly decided that commercial parodies could claim protection under the fair use defense.

The Court then defined parody and distinguished it from a work of satire. ${ }^{82}$ A parody, the Court stated, "needs to mimic an original to make its point, and so has some claim to use the creation of its victim's ... imagination, whereas satire can stand on its own two feet and so requires justification for the very act of borrowing. ${ }^{83}$ Thus, the Court found that a derivative work is only a parody capable of fair use protection if the work could "reasonably ... be perceived as commenting on the original or criticizing it, to some degree."\$4 Finally, under the first factor, the Court explicitly warned against treating a commercial use as presumptively unfair, as it determined that such purpose "is only one element of the first factor enquiry. ${ }^{85}$ The Court concluded that the Court of Appeals erred in holding that 2 Live Crew's parody presumptively was unfair. ${ }^{86}$

Considering the second factor, the nature of the copyrighted work, ${ }^{87}$ the Court found that the creative aspect of Orbison's underly-

${ }^{79}$ Id. at 579 (citations omitted); see also Pierre N. Leval, Campbell v. Acuff-Rose: Justice Souter's Rescue of Fair Use, 13 CARDOZO ARTS \& ENT. L.J. 19, 23 (1994) [hereinafter Rescue of Fair Use] (stating that the Court's opinion in Campbell "thus restores the lost emphasis on 'productive use,' but now in the context of a far more sophisticated discussion, related in every detail to the basic objectives of copyright doctrine").

${ }^{80}$ See Campbell, 510 U.S. at 579 (determining that "[s] uch works thus lie at the heart of the fair use doctrine's guarantee of breathing space within the confines of copyright").

Id.

${ }^{82}$ See id. at 580-81 (defining a parody, for the purposes of copyright law, as "the use of some elements of a prior author's composition to create a new one that, at least in part, comments on that author's works"). In a footnote, the Court defined a satire as "a work "in which prevalent follies or vices are assailed with ridicule." Id. at $581 \mathrm{n} .15$ (quoting 14 OXFORD ENGLISH DICTIONARY 500 (2d ed. 1989)).

${ }^{83}$ Id. at 580-81.

${ }^{84}$ Id. at 583.

${ }^{85}$ Id. at 584 . The Court stated, however, that "the force of that tendency will vary with the context." Id. at 585 .

${ }^{86}$ See id. at 583-84.

${ }^{87}$ The second factor requires courts to recognize that some works are better in- 
ing work "is not much help in this case, or ever likely to help much in separating the fair use sheep from the infringing goats in a parody case, since parodies almost invariably copy publicly known, expressive works. ${ }^{\text {"88 }}$

As to the third factor, the substantiality of the portion used in relation to the copyrighted work as a whole, the Court pointed to the first factor, the parodic purpose of the use, and the fourth factor, the potential market harm on the original work. ${ }^{89}$ The Court noted, as previous courts have, ${ }^{90}$ that when a parody targets an original work, it must be able to "conjure up" at least enough of the work to enable audience recognition. ${ }^{91}$ The more that an original is copied verbatim, however, the less transformative the value, and the more likely a negative effect on the value of the original will occur. ${ }^{92}$ The Court remanded to the lower court for a determination of whether 2 Live Crew's use amounted to excessive copying. ${ }^{93}$

Finally, the Court found that, in addressing the fourth factor, courts should consider the transformative nature of the parody rather than its commercial nature when evaluating the parody's likely market harm to the original. ${ }^{94}$ The Court reasoned that the more transforma-

tended for copyright protection than others. See id. at 586 (concluding that it is more difficult to establish fair use when works "closer to the core of intended copyright protection" are copied). To be copyrightable under $\S 102$, a work must be an original work of authorship. See 17 U.S.C. \$ 102(a) (1994). Those works with creative expressions, as opposed to merely factual works, get a higher level of copyright protection. See Feist Publications, Inc. v. Rural Tel. Serv. Co., 499 U.S. 340, 362 (1991) (explaining that the creator's work "lacks the modicum of creativity necessary to transform mere selection into copyrightable expression"); supra note 30 (discussing the requirement of creativity). Thus, a finding of fair use is more likely when the underlying work is one of factual nature. See Stewart v. Abend, 495 U.S. 207, 237 (1990) (reasoning that there is greater need to distribute factual works than works of fiction).

${ }_{89}$ Campbell, 510 U.S. at 586.

${ }^{89}$ See id. at 586-87 ("[T] he extent of the permissible copying varies with the purpose and character of the use.... The facts bearing on [the third] factor will also tend to address the fourth ....").

${ }^{90}$ See supra notes 65-68 and accompanying text (discussing other courts' analyses of the third factor in parody cases).

${ }^{91}$ See Campbell, 510 U.S. at 588 (stating that a parody should take "at least enough of that original to make the object of its critical wit recognizable").

${ }^{92}$ See id. at 587-88 ("[A] work composed primarily of an original, particularly its heart, with little added or changed, is more likely to be a merely superseding use, fulfilling demand for the original.").

${ }^{95}$ See id. at 589 ("As to the music, we express no opinion whether repetition of the bass riff is excessive copying, and we remand to permit evaluation of the amount taken $\cdots . .$.$) .$

${ }^{94}$ See id. at 591 (examining the effects of transformation from duplication and concluding that transformative uses are less likely to cause market harm). 
tive a parody, the less certain market substitution becomes. ${ }^{95}$ In that light, the transformative parody and the original "usually serve different market functions." ${ }^{96}$ Furthermore, the role of the courts is to distinguish those parodies that actually harm the market for the original from those that merely suppress demand through criticism. ${ }^{97}$

The Court emphasized that the potential negative effect on Orbison's market for licensing potential derivative works also must be examined. That is, the Court required an inquiry into whether "a potential rap market was harmed in any way by 2 Live Crew's parody, rap version. ${ }^{98}$ The Court then remanded for a determination of the severity of harm to the market for the original caused by 2 Live Crew's song.

Although the Supreme Court's decision arguably provides the lower courts with a detailed framework from which to tackle the fair use defense for works of parody, ${ }^{100}$ it left much discretion to the lower courts. Importantly, the Court required a threshold determination that the work criticizes or comments on the original work, and thereby qualifies as a parody rather than a satire, which bolsters an argument for the fair use defense. ${ }^{101}$ The required threshold determination poses the threat that lower courts will overemphasize the distinction between parody and satire in evaluating the remaining statutory factors. ${ }^{102}$ Given this type of subjective analysis, the lower courts are

${ }^{95}$ See id. at 580 n.14 (explaining that market substitution may occur where "a parody whose wide dissemination in the market runs the risk of serving as a substitute for the original or licensed derivatives").

${ }^{96}$ Id. at 591.

${ }^{97}$ See id. at 592-93 (stating that "the role of the courts is to distinguish between '[b]iting criticism [that merely] suppresses demand [and] copyright infringement[, which] usurps it" (alteration in original) (quoting Fisher v. Dees, 794 F.2d 432, 438 (9th Cir. 1986))). Addressing the market for other parodies, the Court cautioned that "there is no protectible derivative market for criticism. The market for potential derivative uses includes only those that creators of original works would in general develop or license others to develop." Id. at 592.

Id. at 593.

${ }^{99}$ See id. at 594 (asserting that " $[\mathrm{t}]$ he evidentiary hole [on the fourth factor] will doubtless be plugged on remand").

${ }^{100}$ See Rescue of Fair Use, supra note 79, at 23 (submitting that the Campbell decision "has restored valid compass bearings to the fair use doctrine by relating it in each of its component inquiries to the overarching central purpose of copyright").

${ }^{101}$ See supra notes 82-84 and accompanying text (defining parody and satire, and distinguishing between the two).

${ }^{102}$ In Dr. Seuss Enterprises v. Penguin Books USA, Inc., the Ninth Circuit determined that the defendant could not claim fair use of Dr. Seuss's copyrighted material. See 109 F.3d 1394, 1406 (9th Cir. 1997) (affirming the district court's injunction order prohibiting publication and distribution of the work). The court, applying the parody/satire 
cast as "gatekeeper[s] to fair use protection,"103 and parodists and authors may continue to face uncertainty in lower court opinions. ${ }^{104}$

\section{AN ECONOMIC APPROACH TO THE FAIR USE DEFENSE AND PARODY}

\section{A. Basic Economic Principles}

Because the law of copyright is based on economic principles, ${ }^{105}$ economic theories may provide a pathway around the obstacles that arise from parody cases. Since every fair use analysis requires an exploration into the fundamental tenets of copyright law, ${ }^{106}$ economic

distinction discussed in Campbell, found that the defendant's book, "The Cat NOT in the Hat!" was a satire because it failed to target the "substance" of the underlying work. See id. at 1401 (suggesting that the authors mimicked Dr. Seuss's style for attention and ease, not criticism or ridicule). The categorization of the work as a satire has been criticized as a narrow construction of the threshold determination as defined by Campbell. See, e.g., Mary L. Shapiro, Comment, An Analysis of the Fair Use Defense in Dr. Seuss Enterprises v. Penguin, 28 GOLDEN GATE U. L. REV. I (1998); Jason M. Vogel, Note, The Cat in the Hat's Latest Bad Trick: The Ninth Circuit's Narrowing of the Parody Defense to Copyright Infringement in Dr. Seuss Enterprises v. Penguin Books USA, Inc., 20 CARDOZO L. REV. 287 (1998). Rather than addressing whether a new work could "reasonably be perceived" as having a parodic character in order to qualify as a parody, the Ninth Circuit relied on Justice Kennedy's concurrence-that a parody "target[s] the original, and not just its general style, the genre of art to which it belongs, or society as a whole." Dr. Seuss, 109 F.3d at 1400 (citing Campbell, 510 U.S. at 597 (Kennedy, J., concurring)). The Ninth Circuit's determination that the purpose of the work was not parody, but satire, heavily influenced the court in its analysis of the remaining statutory factors. See Dr. Seuss, 109 F.3d at 1399-1403.

Another court recently implemented this threshold distinction in a case where the use more clearly qualified as a satire. In Williams v. Columbia Broadcasting Systems, Inc., the court found that the use of a "Saturday Night Live" character, "Mr. Bill," was "unquestionably intended as a good natured jibe of the Navy and its personnel," and not of the original character. 57 F. Supp. 2d 961, 968-69 (C.D. Cal. 1999) (citing Campbell, 510 U.S. at 597 (Kennedy, J., concurring)). In classifying the segment as a satire, the court stated that "[a] parody does not gain protection of the Fair Use Doctrine if it merely uses the protected work as a means to ridicule another object." Id. (citing Campbell, 510 U.S. at 580).

${ }^{103}$ Kathryn D. Piele, Three Years After Campbell v. Acuff-Rose Music, Inc., What Is Fair Game for Parodists?, 18 LOY. L.A. ENT. L.J. 75, 98 (1997).

${ }^{104}$ See id. at 79 (arguing that the distinction between satire and parody should be left to the parodists). Piele found that "at least one district court ... made a distinction between a satire and a parody that appears to directly contradict common sense." Id. at 94. Furthermore, "[a]t best, the differentiation between parodies and satires is strained. Courts should not have the discretion to make a subjective determination about what an original work represents or what a secondary work is attempting to say about it." Id. at 98.

${ }^{105}$ See Mazer v. Stein, 347 U.S. 201, 219 (1954) (noting the "economic philosophy" underlying Congress's power to grant monopoly protection to authors).

${ }_{106}$ See Campbell, 510 U.S. at 577 ("The fair use doctrine thus "permits [and requires] courts to avoid rigid application of the copyright statute when, on occasion, it 
models should guide courts in analyzing and applying the fair use defense in parody cases. ${ }^{107}$ Indeed, as Professor Fisher states: "economic[s] ... proves capable of providing insights into the fair use doctrine that all but the staunchest critics of the methodology would find helpful." ${ }^{\text {"108 }}$

\section{Economics of Copyright Law}

The goal of most economic analyses is to arrive at an economically efficient solution. ${ }^{109}$ A Kaldor-Hicks efficient solution represents "that allocation of resources which could not be improved in the sense that a further change would not so improve the condition of those who gained by it that they could compensate those who lost from it and still be better off than before. ${ }^{\text {"110 }}$ A central idea in modern economics is that self-interested actions of individuals lead to an efficient solution

would stifle the very creativity which that law is designed to foster." (alteration in original) (quoting Stewart v. Abend, 495 U.S. 207, 236 (1990))).

${ }^{107}$ See Robert P. Merges, Are You Making Fun of Me?: Notes on Market Failure and the Parody Defense in Copyright, 21 AIPLA Q.J. 305, 306 (1993) ("[C]ourts and commentators are converging on a view of copyright that emphasizes the economic structure of its rules and doctrines."); see also William W. Fisher III, Reconstructing the Fair Use Doctrine, 101 HARV. L. REV. 1661, 1696-97 (1988) (arguing that "many judges are likely to be attracted to an economic approach-not only because of the current general popularity of the method, but also because intellectual property law has long been considered a field especially amenable to instrumental modes of analysis").

${ }^{108}$ Fisher, supra note 107, at 1697.

109 See A. MITCHELl POLINSKY, AN INTRODUCTION TO LAW AND ECONOMics 7 (2d ed. 1989) ("Economists traditionally concentrate on how to maximize [efficiency, or] the size of the pie ...."). Efficient solutions are defined technically as "Pareto efficient" or "Pareto optimal." Id. at 7 n.4. A Pareto efficient solution exists if there is no change possible to make one person better off without making another worse off. Stated another way, a solution is inefficient if one person can be made better off without making anyone else worse off. See id.

A related concept is Kaldor-Hicks efficiency. "A Kaldor-Hicks efficient state of affairs is one in which no individual or group of individuals can be made better off without inflicting losses on others which exceed the amount of the gains." Yen, supra note 48, at 94; see also ROBERT COOTER \& THOMAS ULEN, LAW AND ECONOMICS 12 (3d ed. 2000) (providing an example of a Pareto efficient solution).

${ }^{110}$ Guido Calabresi \& A. Douglas Melamed, Property Rules, Liability Rules, and. Inalienability: One View of the Cathedral, 85 HARv. L. REv. 1089, 1094 (1972). An efficiency analysis stems from the assumption that the value a person places in property reduces to money, and that money can always be redistributed among individuals without any additional cost. SeeYen, supra note 48, at 106 (discussing the fungible nature of money and its role in efficiency analysis). This assumption is important in reducing the analysis to a single scale "by which to measure the consequences of changing any status quo." Id. For an explanation of the conditions required to reach an efficient solution, see infra note 113. 
under certain conditions. ${ }^{111}$ The pursuit of self-interest promotes a number of mutually beneficial transactions, or voluntary exchanges, which continue until further possibility of such beneficial exchanges is exhausted. ${ }^{112}$ Such exchanges will lead to an efficient state under perfect market conditions, regardless of the legal rule given effect. ${ }^{113}$

In the exchange of copyrighted works, however, perfect market conditions do not exist. ${ }^{114}$ The monopoly protection granted to authors is a necessary incentive due to the unique nature of copyrighted works as public goods, an aspect which functions as a market impediment. ${ }^{115}$ A public good, as distinguished from a private good, has two defining characteristics. First, the public good may be used by an unlimited number of people without exhausting it as a resource. ${ }^{116}$ Second, those who benefit from the use of a public good may not easily prevent others from enjoying the benefits as well. ${ }^{117}$ That is, once

111 SeeYen, supra note 48, at 95 (indicating that the proposition "flows from the assumption that rational individuals will pursue what they subjectively believe is in their self interest").

${ }^{112}$ See id.

113 See Gordon, supra note 24, at 1611. This proposition, entitled the "Coase Theorem," was first developed in an article by Robert Coase. See R. H. Coase, The Problem of Social Cost, 3 J.L. \& ECON. 1 (1960). For a detailed explanation of the Coase Theorem, see POLINSKY, supra note 109, at 11-14.

There are three perfect market conditions, or "conditions of perfect competition," that must be satisfied to result in an efficient solution. Gordon, supra note 24 , at 1607 . First, all costs and benefits must be borne by the persons within the transaction and not by persons external to it. See id. (indicating that "external benefits" may affect a resource user's "willingness to pay for the resource" and "might understate his ability to use [the resource] in a way that serves social needs"). Second, perfect market conditions also "require[] perfect knowledge; for example, consumers must know the qualities and characteristics of all available products, as well as the prices and locations of the various sellers." Id. (citations omitted). Finally, perfect competition requires the absence of transaction costs. See id. at 1608 (noting that "it must be costless" to "obtain knowledge,... locate all persons affected by a transaction," bargain over "prices and terms," and "maintain an enforcement mechanism to ensure [adherence to the bargain]").

${ }^{114}$ See Winslow, supra note 55, at 773 (determining that perfect market conditions do not exist due to the characterization of copyrighted works as public goods).

${ }_{115}$ See Landes \& Posner, supra note 2, at 326 ("A distinguishing characteristic of intellectual property is its "public good' aspect.").

${ }^{116}$ See Lydia Pallas Loren, Redefining the Market Failure Approach to Fair Use in an Era of Copyright Permission Systems, 5 J. INIELL. PROP. L. 1, 22-23 (1997) (discussing the public good nature of copyrighted works). A public good is a good for which no one competes (non-rivalrous) and that no one owns exclusively (non-excludable). In contrast, a private good may only be consumed once. See Winslow, supra note 55, at 773 n.26 (citing ROBERT COOTER \& THOMAS ULEN, LAW AND ECONOMICS (2d ed. 1996)).

${ }^{117}$ See COOTER \& ULEN, supra note 109, at $42-43$ (discussing the free-rider problem with public goods). 
the good is provided for any individual, its enjoyment, in practice, naturally extends to everyone else in society. Thus, because those who have not paid (often referred to as "free-riders") 118 may use the good, "public goods usually will be under-produced if left to the private market. "119

Since it is not possible for the military to defend a particular house from nuclear attack while leaving the neighbor's house vulnerable to enemy fire, national defense serves as a classic example of a public good. ${ }^{220}$ Some individuals would purchase the defense, but many people rationally would rely on their neighbors to purchase the protection. Because a private national defense provider could not possibly discriminate by providing service only to those who paid, there would be a shortage of national defense produced, as the amount of funding received would not adequately compensate the private firm. ${ }^{121}$ The free-rider principle, therefore, suggests that "unless there is coercion or some other special device to make individuals act in their common interest, rational, self-interested individuals will not act to achieve their common or group interests." 122

Similarly, books and other creative works subject to copyright protection also possess qualities of public goods. ${ }^{123}$ An author likely will not be willing to incur the costs to create a work if free-riders may copy that work without adequately compensating her. At a minimum, the author will seek to recover those costs associated with creating the work. ${ }^{124}$

The costs associated with creating or authoring a work, however, almost always are higher than the costs associated with reproducing the work. As a result, the value placed on a work by society may exceed what an author is able to capture, and the author may not have

118 Id

119 Gordon, supra note 24, at 1611.

120 See COOTER \& ULEN, supra note 109, at 42 (discussing the public good nature of national defense).

121 See id. ("If private profit-maximizing firms are the only providers of national defense, too little of that good will be provided.").

${ }^{122}$ Mancur Olson, The Logic of Collectrve ACtion 2 (1965).

${ }^{123}$ See Gordon, supra note 24, at 1611 ("Books and inventions exhibit certain public goods characteristics.").

${ }_{124}$ See Landes \& Posner, supra note 2, at 327. The costs associated with creating a work, or the "cost of expression," primarily include "the author's time and effort plus the cost to the publisher of soliciting and editing the manuscript and setting it in type." Id. It is assumed that an author will only create a work if the difference between the expected revenues from the books and the cost of making copies for sale equals or exceeds the cost of expression. See id. 
sufficient incentive to invest her creativity in the work. ${ }^{125}$ Thus, in order to allow the author to adequately capture some of the public value of her work, copyright protection grants the power to prevent others from freely copying the work at a low cost of reproduction. ${ }^{126}$ Copyright law implements proper economic incentives by permitting an author to sell copies at a price that reflects, at a minimum, the cost of creation.

Nevertheless, there are three reasons why an overemphasis on incentives to authors would unduly restrict societal access to desired works. First, the greater the public access to information, the more efficiently markets will operate. ${ }^{127}$ Second, as explained above and again in economic terms below, authors frequently build upon previous works to create new ones. ${ }^{128}$ Access to prior works lowers the costs of creating new ones, ${ }^{129}$ which is socially desirable. ${ }^{130}$ Finally, granting an unconstrained monopoly to an author forces certain consumers out of the market. ${ }^{131}$ Fortunately, copyright law addresses the need for flexibility by recognizing the societal goal of access to copyrighted

125 See Loren, supra note 116 , at 23 (noting that the public good nature of a work can reduce an author's incentive to create).

${ }^{126}$ See id. (describing the inventive-based rationale in copyright law that motivates authors to invest a socially optimal amount of effort in their creations).

${ }^{127}$ See Winslow, supra note 55, at $774 \&$ n.32 (stating that it is better for the market, and therefore in the public interest, that private economic decisions are well informed).

${ }^{128}$ See Yen, supra note 48, at 81 ("If copyright law outlawed all borrowing from existing works, the creative process would surely grind to a halt, thereby depriving the public of the very benefits copyright should secure."); supra notes 33-36 and accompanying text (explaining why the monopoly granted to authors may be too broad).

${ }^{129}$ See Winslow, supra note 55, at 774 (noting that "the less authors may borrow from previous works, the more costly it is for them to create new ones" (citation omitted)).

Here I assume that there is no material limit on the amount of books that society needs. There may be, however, an overproduction of books, in which case a lower cost of creation will not necessarily be socially desirable.

${ }^{131}$ See Fisher, supra note 107, at 1700-05 (discussing the determination of "optimal levels of copyright protection"). Monopoly protection results in a certain inefficiency termed "deadweight loss." Id. at 1702. Deadweight loss stems from the concept that one receiving monopoly protection will only charge up to a point where the marginal revenue (the revenue from the last itern sold) exceeds the cost of the last item sold. But, as the monopolist charges a price substantially higher than the marginal cost of that good, those consumers who would have paid above the marginal cost, but below the monopoly price, will refuse to buy. See id. at 1702-03.

Thus, deadweight loss, as "measured by the total of the consumer surplus that would have been reaped by the excluded consumers and the producer surplus that would have been reaped by the copyright owner had he sold the work to them," results. Id. at 1702 . 
works. The Copyright Act achieves this by limiting the duration of the monopoly, ${ }^{132}$ and by allowing borrowing from prior works even during copyright protection through fair use. ${ }^{133}$ To evaluate fully the economic justifications for fair use, it is first necessary to explore the allocation of the right to prepare derivative works.

\section{The Economics of Derivative Works}

In addition to the right to control the reproduction of a copyrighted work, copyright law allows an author to prevent others from preparing derivative works. ${ }^{134}$ Economically, granting this right to an author furthers the goal of copyright law: to "induce the production of the greatest amount of original works of authorship at the lowest cost." ${ }^{135}$ Yet, a precise economic justification for allocating this right to an author, as opposed to a derivative author, is not without dispute.

Unlike the right to control reproduction of works, failure to allocate control over derivative works to an author is not likely to impede the author's ability to recoup the fixed costs of creation. ${ }^{136}$ A derivative work is either an imperfect substitute for the original or is not a substitute at all. ${ }^{137}$ For example, although a movie based on a play may slightly affect the demand for the original, it will not necessarily usurp the demand for the play. ${ }^{138}$ A person who wants to see the play in English will not likely see or read the German translation of the play. ${ }^{139}$ As Professor Landes and Judge Posner found, "it would be speculative to conclude that without control over derivative works authors and publishers would not be able to cover the fixed costs of the original work." ${ }^{140}$ Economic justification, therefore, must be found elsewhere.

Another justification for allocating the right to an original author, rather than allowing free copying by a derivative author, may be to

${ }^{132}$ See I7 U.S.C. $\$ 302$ (1998) (limiting generally the copyright term to life plus seventy years).

${ }^{139}$ See supra note 23 (discussing the fair use doctrine as a doctrine within copyright law that allows taking from copyrighted works to achieve the goal of sufficient access).

${ }^{134}$ See supra notes $25-31$ and accompanying text (defining the rights of a copyright owner and explaining derivative works).

${ }^{135}$ Winslow, supra note 55, at 780.

${ }^{136}$ See Landes \& Posner, supra note 2, at 353-54 (discussing the scope of legal protection associated with derivative works).

${ }^{137}$ See id. at 353-57 (explaining the concept of a derivative work).

${ }^{138}$ See Winslow, supra note 55, at 781 (arguing that a derivative work will not "undermine the original author's ability to recoup the fixed costs").

${ }_{139}$ See id.

${ }^{140}$ Landes \& Posner, supra note 2, at 354. 
provide an incentive for the timely creation and dissemination of works. ${ }^{141}$ This justification assumes that an author may create with the expectation of a high demand for derivative works. Yet, as uncertainty about demand for the original work is a concern upon creation, ${ }^{142}$ uncertainty regarding the market is an equal or greater concern for derivative works. Expectation of related revenue, thus, may be too speculative to provide a persuasive incentive to create. ${ }^{143}$ Moreover, if the law granted a derivative author copyright protection, the original author may have an incentive to delay publication until the author has created, or licensed the right to create, a derivative work in order "to gain a head start on any would-be author of such a work." "144 For example, to capture the maximum profit from a new play, an author likely would delay publication or production of the play until she licensed the rights to make the related motion picture.

Professor Landes and Judge Posner posit an additional economic justification for granting an original author a monopoly over derivative works: achievement of the lowest possible transaction costs. ${ }^{145}$ For example, without such an allocation, a publisher who wanted to publish a translation, written in a different language than that of the original work, would have to transact with both the original author and the translator. As stated by Landes and Posner, "this transaction, with its attendant costs, can be avoided if the law places the power to obtain both copyrights in the same person to begin with-and that is, in effect, what the law does. ${ }^{\text {1146 }}$ Many scholars agree that, on balance,

${ }^{141}$ See id. at 355 (explaining the consequences if the derivative, not the original, author is allowed to copyright derivative works).

${ }_{142}$ See id. at 328 ("Uncertainty about demand is a particularly serious problem with respect to artistic works, such as books, plays, movies, and recordings. ... Sales may be insufficient to cover the cost of expression....").

${ }^{143}$ See id. at 354 (commenting on the speculative nature of the expectation of the revenues from derivative works).

${ }^{144} I d$. at 355. Posner and Landes state that this reasoning also may exist in the realm of fair use. The fair use defense is less likely to succeed when a defendant copies unpublished works. See Harper \& Row, Publishers, Inc. v. Nation Enters., 471 U.S. 539, 569 (1985) (holding that a magazine's publication of an unauthorized copy of a manuscript is not fair use under the Copyright Act). Otherwise, "authors would have an incentive to incur heavy expenditures to prevent anyone from gaining access to the works." Landes \& Posner, supra note 2, at 355 n.39.

${ }_{145}$ See Landes \& Posner, supra note 2, at 355 (proposing reduction of transaction costs as a reason for giving an original author a monopoly over derivative works).

${ }_{146}^{14}$ Id; see also Richard A. Posner, When Is Parody Fair Use?, 21 J. LEGAL STUD. 67, 69 (1992) ("It does not matter how much . . . commercially more valuable ... the derivative work is. Transaction costs are minimized when all rights over the copyrighted work are concentrated in a single pair of hands."). 
providing the original author with control over the preparation of derivative works is the most efficient allocation of such rights. ${ }^{147}$ Nevertheless, as the contributions of a derivative author and the value society places on that work increase, the more incentive a derivative author has, and the stronger the case becomes to allocate control to her. ${ }^{148}$

\section{The Economics of Parodies and Fair Use}

Works of parody involve "both a taking from a previous work and an injection of creativity, large or small. ${ }^{149}$ Because successful parody requires taking enough copyrighted material to distort "the most striking peculiarities of subject matter and style" of an original,,$^{150}$ an infringement likely occurs against the copyright holder, who has the right to prepare the derivative work. ${ }^{151}$ Parodies, however, possess certain qualities that distinguish them from other derivative works and, as a result, weaken the efficiency argument in favor of granting an original author control of such works.

Most parodies provide the public with both a popular form of humor and a critical perspective of the original work..$^{152}$ Frequently, parodists receive substantial financial rewards because society places a high value on this type of work. ${ }^{153}$ Efficiency analysis suggests that a parodist should bargain with an author and purchase the right to pre-

${ }^{147}$ See Landes \& Posner, supra note 2, at 354-55 (arguing that it is optimal to put the right to prepare derivative works in the hands of the original author to promote optimum timing of publication and to reduce transaction costs); Yen, supra note 48 , at 95-97 (arguing that authors of derivative works may use the money they earn from the work to pay original authors, which in turn increases the original authors' financial incentives to create more material-a design that is assumed to be efficient as long as the rights to create the work are more valuable in the borrower's hands than in those of the author).

${ }^{148}$ See Winslow, supra note 55, at 782 (recognizing that "a case can be made for favoring derivative authors").

${ }_{149}$ Posner, supra note 146, at 68 (citation omitted); see also supra notes 17 \& 82 (defining parody).

Id.

151 See Yen, supra note 48, at 85-86 (" $[I]$ t is clear that parodies infringe the author's right to control creation of 'derivative works.' Since parodies always borrow and recast the plot, words, and style of a preexisting original, they necessarily fall under the definition of derivative work.").

${ }^{152}$ See id. at $88-89$ (arguing for "a cost-benefit analysis of the social consequences" associated with parodies).

${ }^{153}$ See id. at 100 (implying that a derivative work's social value is reflected in the price the public will pay for the work). 
pare a derivative work. ${ }^{154}$ Unlike other derivative works, however, the sale of parody rights involves potential humiliation to the author of the underlying work. ${ }^{155}$ If a parody provided the public with nothing more than "a good laugh," most authors would not hesitate to license their works, with the exception of authors of serious works who object to their works being the subject of humor. In addition to humor, however, parodies achieve a level of criticism. ${ }^{156}$ As such, those "[a]uthors anxious to avoid being humiliated will seldom, if ever, voluntarily expose their own work to a critical parody." 157 Such refusal to license may be described as a no-consent case, where a transaction fails due to an author's motive to censor. ${ }^{158}$

For three reasons, the prevalence of no-consent cases in the parody context deflates the efficiency arguments that favored allocating original authors the right to derivative uses. First, the public interest in the dissemination of works of criticism presumably is strong for works of parody. ${ }^{159}$ Such external benefits to society derived from works of parody (referred to as "externalities" ${ }^{\text {"160 }}$ ) will lead to ineffi-

${ }^{154}$ See id. (noting that economists assume "that individuals who want to create derivative works will raise sufficient money to buy the necessary rights from the author ${ }^{n}$ ).

${ }^{155}$ See id. at 93 (" $[\mathrm{T}]$ he sale of parody rights is vastly different from the sale of other derivative rights.").

${ }^{156}$ See id. at 91 (recognizing that parodies provide "a very unique criticism of literary and social foibles").

${ }^{157} I d$. at 93 . This result is also supported by empirical studies. See id. at 106 (discussing empirical evidence based on libel actions).

${ }^{158}$ See Winslow, supra note 55, at 793 (defining a no-consent case). A no-consent case is distinguished from an implied-consent case, where an author is unwilling to transact because of prohibitively high transaction costs. See id. at 793-99. Such a distinction stems from the language of the Supreme Court, describing fair use that is "'based on authors' implied consent to reasonable uses of their works, or on an exception to authors' monopoly privileges needed in order to fulfill copyright's purpose to promote the arts and sciences." Id. at 793 n.145 (quoting American Geophysical Union v. Texaco, Inc., 37 F.3d 881, 884 (2d Cir. 1994)).

${ }^{159}$ See Gordon, supra note 24, at 1634 ("Criticism is valuable, inter alia, because the market works to further the social good only when consumers have accurate information about the goods available."); supra text accompanying notes 53-54 (describing the importance of the fair use defense for works of parody).

${ }^{160}$ Externalities are those benefits or costs of an exchange that "may spill over onto other parties than those explicitly engaged in the exchange." COOTER \& ULEN, supra note 109, at 40. An example of an external benefit, or positive externality, occurs when every neighbor in a neighborhood enjoys the beauty of a single neighbor's landscape. An example of an external cost, or negative externality, occurs when every member of a community coughs from one company's air pollution. Due to the inability of each producer to internalize the costs or benefits of the action, the positive externality will likely be underproduced and the negative externality will likely be overproduced in the absence of taxes or subsidies. See id. at 39 (providing examples of external costs and benefits). 
ciency. ${ }^{161}$ As the societal benefit extends far beyond that which may be captured by the parodist, these positive externalities "are impossible to internalize in any bargained-for exchange between the copyright owner and the [parodist]." ${ }^{162}$ Thus, even though the dissemination of the parody may be value-maximizing, the work will remain in the hands of the original author. ${ }^{163}$ In such a case, the fair use doctrine supplies the beneficial exchange where the market will not.

Second, in a no-consent case, the original author who refuses to license effectively denies a market for works of parody. Consequently, preventing delay in the dissemination of works no longer provides justification for allocating the monopoly over derivative works to the original author. ${ }^{164}$ Finally, any benefit, conferred by minimizing transaction costs through concentrating the copyrighted work "in a single pair of hands, ${ }^{165}$ is not realized without a transaction. Thus, in the context of parody, efficiency concerns only weakly favor the original author, if at all. ${ }^{166}$ The fair use defense for works of parody, therefore, may save an otherwise inefficient allocation of rights.

\section{B. Economic Models for Fair Use and Parody}

\section{Previous Economic Models Addressing Fair Use for Works of Parody}

Four scholars recently have formulated economic models to address the fair use defense for works of parody. ${ }^{167}$ First, the market failure approach, introduced by Professor Gordon in 1982, states that a court should employ the fair use doctrine only when the market does not provide socially desirable access to, and use of, copyrighted works,

161 See Gordon, supra note 24, at 1630 (finding that, due to externalities, "the market cannot be relied upon as a mechanism for facilitating socially desirable transactions").

${ }^{162}$ Loren, supra note 116, at 49.

${ }^{165}$ See id. at 50 ("The inability to internalize significant external benefits is a type of market failure that fair use must protect.").

${ }^{164}$ See Winslow, supra note 55, at 785 (stating that authors will not be induced to create based on the prospect of licensing the right to prepare a parody, nor will they likely delay publishing their work until they license parodies).

${ }_{165}$ Posner, supra note 146, at 69.

${ }^{166}$ See Winslow, supra note 55, at 785 (arguing that the right of control over derivative works "constitute[s] at best a marginal inducement to more original creation").

${ }^{167}$ In 1988, Professor William Fisher wrote an important article that examined the fair use defense from an economic perspective. See Fisher, supra note 107, at 16981744. Although other scholars have relied on Fisher's insights to formulate their own economic models, his model is not discussed in detail in this Comment. 
and even then, only if the original author would not be injured substantially from the uncompensated use. ${ }^{168}$ To evaluate market failure, Professor Gordon provides a three-part test to analyze all fair use cases. $^{169}$

The first prong of the test requires a court to evaluate the market and determine if a reason to mistrust it exists. ${ }^{170}$ Professor Gordon suggests that both the impossibility or difficulty in achieving a market bargain, and the existence of externalities and nonmonetizable interests, provide reasons to mistrust the market. ${ }^{171}$ In the second part of the test, a court should determine if "the transfer to the defendant [is] value-maximizing, as determined by weighing plaintiff's injury against defendant's social contribution. ${ }^{172}$ Finally, if the first two conditions are satisfied, the court should determine if a fair use would cause the copyright owner substantial injury. ${ }^{173}$ If not, fair use should be awarded to the defendant. ${ }^{174}$

In applying Gordon's model to works of parody, transferring the right to prepare a work of criticism to the defendant may be valuemaximizing because of the high social value of that form of criticism. Information about the original work, including revelations of its flaws, may be generated only through such critique. Further, reasons to mistrust the market probably exist due to the anti-dissemination motives of authors who are "unlikely to license a hostile review or a parody" of their own work. ${ }^{175}$ Market failure should be found, however, "only when the defendant can prove that the copyright owner would

${ }^{163}$ See Gordon, supra note 24, at 1657 (asserting that the market failure approach is not a justification for court intervention whenever the market fails to reach "perfect" results).

${ }^{169}$ See id. at 1626-27. Professor Gordon suggests the three-part test best incorporates the economic functions served by copyright and the internal dynamics of the copyright statute. Gordon provides evidence of the market approach in court decisions and congressional legislation. The description of her three-part test utilizes only those portions which are relevant to the issue of parody, thus leaving out certain discussions of fair use, such as for educational purposes.

${ }^{170}$ See id.

171 See id. at 1627-32 (describing why market barriers, such as transaction costs, external benefits and costs, and nonmonetizable interests, such as contribution to public knowledge, are reasons for mistrusting the market).

${ }^{172}$ Id. at 1626; see also id. at 1615-17 (explaining that "[i]f when the 'market failure' were cured, the price that the owner would demand is lower than the price that the user would offer, a transfer to the user will increase social value").

${ }^{173}$ See id. at 1618-22 (describing the functions of the "substantial injury hurdle").

${ }^{174}$ See id. at 1618 ("Fair use should be denied whenever a substantial injury appears that will impair incentives.").

${ }^{175}$ Id. at 1633 . 
refuse to license out of a desire ... to keep certain information from the public."176 Thus, for works of parody, one pivotal focus of Gordon's analysis is the nature of an author's reluctance to license.

In 1992, Judge Posner provided an economically based, threepronged model for a parody defense. ${ }^{177}$ The first prong of Posner's rnodel distinguishes between parodies that use a copyrighted work as a weapon to criticize or comment on something else, and those where the target of the parody is the copyrighted work itself. ${ }^{178} \mathrm{He}$ argues that the fair use defense should be available for the latter, but not for the former. ${ }^{179}$ This proposal apparently turns on the fact that copyright holders, under normal circumstances, will license parodies that use their works as a "weapon" aimed at something else. ${ }^{180}$ As Posner asks rhetorically, "why should the owner of the original be reluctant to license the parody" in such a case ${ }^{181}$ Posner's second prong requires that the defense only be available when the parody does not take such a large fraction of a work as to supplant the market for the original work. $^{182}$ Finally, under Posner's third prong, the taking of a small amount of the original work should not be a permissible fair use, given that some copying is required to achieve an acceptable level of criticism. ${ }^{183}$ Otherwise, Posner argues, a parodist easily could obtain a license to use the work because a market transaction becomes feasible where the parodist does not ridicule the original work. ${ }^{184}$

In 1993, Professor Merges proposed an economic approach to the issue of fair use in parody. ${ }^{185}$ Merges's model focuses on a "transactional, or market-centered, account of the parody defense. ${ }^{\text {,186 }}$ The

${ }^{176}$ Id. at 1634 .

${ }^{177}$ See Posner, supra note 146, at 71-72 (suggesting three limitations on the application of the fair use defense to parodies).

${ }^{178}$ See id. at 71 (recognizing that these uses may overlap and that distinguishing between them can be difficult).

${ }^{179}$ See id. ("[T] he doctrine should provide a defense to infringement only if the parody uses the parodied work as a target rather than as a weapon or ... simply as a resource to create a comic effect.").

${ }^{180}$ See id. (offering examples of works used as weapons to criticize something else). 181 Id.

${ }^{182}$ See id. at $70-72$ ("The parodist should be entitled to take from the original no more than is necessary to make the parody effective.").

${ }^{183}$ See id. at 72.

${ }^{184}$ See id. ("The less the parodist wants to take, the easier it should be for him to obtain a license from the owner of the copyright on the original work.").

${ }^{185}$ See Merges, supra note 107 , at 305 (arguing "that the parody defense makes sense when there is a clear failure in the market for parody licenses").

${ }^{186}$ Id. at 312. 
approach requires courts to determine if "a reasonable market transaction for the right to parody could be envisioned." ${ }^{\text {,187 }}$ According to Merges, the focus on market transaction injects more neutrality into the fair use analysis by allowing "dissemination of every parody capable of generating a net profit to the parodist and copyright holder," rather than relying on a value assessment arising from the distinction of whether a work is a parody or satire. ${ }^{189}$

Merges argues that this determination would be advanced by two pieces of evidence. First, "a consensus of licensing experts agrees that the parody will not appreciably injure the market for the original work." made an offer to pay a royalty that would generously compensate the copyright holder. ${ }^{190}$ The requirements ensure, according to Merges, that the fair use doctrine only applies where a parodist offers adequate compensation to the original author and such offer is refused. ${ }^{191}$

Merges also discusses that the logic of compulsory licensing applies where the costs of entering into a series of voluntary transactions exceed the surplus generated by the parties. ${ }^{192}$ Costs that could impede a transaction include the risk of bargaining breakdown, which is increased by the prospect of an embarrassing parody, or the costs of overcoming a party's noneconomic resistance to bargain. ${ }^{193}$ In those cases, the law must supply a transaction where the market fails. ${ }^{194}$

Finally, in 1996, after the Supreme Court's decision in Campbell, Professor Winslow developed an economic test addressing parodies in a three-part inquiry. ${ }^{195}$ According to Winslow, the model provides an objective standpoint because it tends to avoid content-based distinctions, which separates it from previous models. ${ }^{196}$ First, Winslow directs an inquiry into the likelihood of voluntary exchange, as such an

${ }^{187}$ Id

${ }^{183}$ Id.

${ }^{189} I d$. at 307.

${ }^{190} I d$.

191 See id. at 310 (stating that when the "refusal to license is based on a noneconomic motive... copyright law's preference for dissemination is too strong to give any credence to such motives in such cases").

${ }_{192}$ See id. at 309 (arguing that compulsory licensing is justified only where transactions costs exceed the generated surplus).

193 See id. at 309-10 (defining various transaction costs). plies").

${ }^{194} \mathrm{See}$ id. at 310 (describing cases where "the logic of compulsory licensing ap-

${ }^{195}$ See Winslow, supra note 55, at 809-12 (proposing a new, more neutral approach to the parody defense).

196 See id. at 809. 
inquiry has the desirable effect of encouraging transactions. ${ }^{197}$ In determining such likelihood, one should examine the relationship between the parties and the reasons the original author wants to retain the interest. ${ }^{198}$ Second, the public interest in dissemination should be evaluated according to current case law. ${ }^{199}$ Finally, a court should determine the substantiality of the parodist's adaptations or contributions to the original work. ${ }^{200}$ As the contributions increase, Winslow argues, the greater the chance for fair use protection because it avoids the market substitution ${ }^{201}$ and free-rider problems, ${ }^{202}$ and it strengthens the parodist's claim to resource reallocation because the creativity level is high. ${ }^{203}$

\section{A Proposed Model for Parody and Fair Use}

Based in part on the economic models above, I propose a threepronged economic model to evaluate the fair use defense for works of parody. The model maintains a flexible, case-by-case approach, as required by section 107. The factors of the model are as follows: (1) the nature of the transaction, (2) the strength of the critical element, and (3) the amount of creative contributions. I have chosen each factor to encompass distinct economic considerations. The purpose of the proposed model is to provide a practical method of evaluation by consolidating the economic considerations and models discussed above. ${ }^{204}$

197 See id.

198 See id. at 809-10 (suggesting that a court "look at the conduct and relations of the parties... [and] whether the copyright owner has refused to license the work based on a legitimate desire to retain control over it as opposed to a desire to prevent the publication of a parody").

${ }^{99}$ See $i d$. at 810-11 \& n.223 (arguing that First Amendment principles should be considered when evaluating the public interest in dissemination and explaining that the public interest would be affected by a work that qualifies as obscenity under First Amendment law); see also supra note 37 (discussing the reaction of courts to First Amendment arguments in light of the fair use defense).

${ }^{200}$ See Winslow, supra note 55, at 811-12 (positing that "if the parodist made only trivial changes to the original, then fair use should be denied").

201 See supra note 95.

202 See supra notes 118-19 and accompanying text.

203 See id.

${ }^{204}$ The model is not meant, however, to explain or coincide with existing case law, but to improve on it. 


\section{a. The Nature of the Transaction}

Presumably, parties litigate fair use due to the failure of the market to provide an avenue of voluntary exchange. In the first prong of the inquiry, the nature of the transaction, one should explore the reason for the transaction's failure. As an initial matter, the parodist must demonstrate that she attempted to offer reasonable compensation $^{205}$ to the original author before she used the work. ${ }^{206}$ Of course, considering whether a parodist attempted to transact may contradict that which fair use provides-the allowance of free use of an original author's work. ${ }^{207}$ Placing this initial burden on the parodist, however, ensures at least the possibility of an ex ante transaction between the parties. $^{208}$ If the parodist did not attempt to transact, this first factor, the nature of the transaction, simply should weigh against fair use.

If the parodist sufficiently shows that she attempted to transact, but the original author chose not to license, then the court should examine the reasons for this refusal. ${ }^{209}$ Initially, the parodist must retain

${ }^{205}$ As suggested by Professor Merges, the reasonableness of an offer may be assessed by a consensus of licensing experts. See supra text accompanying note 189 . Alternatively, the reasonableness of an offer may be determined in light of the damages that an original author could win in a successful infringement suit against the defendant. The damages section of the Copyright Act provides:

The copyright owner is entitled to recover the actual damages suffered by him or her as a result of the infringement, and any profits of the infringer that are attributable to the infringement and are not taken into account in computing the actual damages. In establishing the infringer's profits, the copyright owner is required to present proof only of the infringer's gross revenue, and the infringer is required to prove his or her deductible expenses and the elements of profit attributable to factors other than the copyrighted work.

17 U.S.C. $\$ 504$ (b) (1994). In evaluating the nature of the transaction, the burden of proving that the offer was consistent with the expected benefits from the use of the work should rest with the parodist.

${ }^{206}$ For a background discussion of the appropriate allocation of the burden of proof in fair use cases, see Gordon, supra note 24, at 1624-26. Professor Gordon suggests that the defendant should have the initial burden of proving that market failure exists and will continue even if a judgment of liability were tendered. See id. at 1625. If the proof of market failure offered by the defendant leads a court to doubt the presence of injury to the plaintiff, however, "it is legitimate for the court to demand evidence from the copyright owner that such injury would indeed follow... [because t]he harm he has suffered or anticipates is an area that should be peculiarly within plaintiff's knowledge." Id. at 1626.

${ }^{207}$ See, e.g., Campbell v. Acuff-Rose Music, Inc., 510 U.S. 569, 585 n.18 (1994) ("If the use is otherwise fair, then no permission need be sought or granted.").

${ }^{208}$ For a discussion of how voluntary transactions lead to efficiency, see supra notes 111-13 and accompanying text. For the purposes of this model, I assume that an ex ante transaction is preferable to fair use litigation, regardless of the outcome.

200 Evaluating the nature of the transaction addresses the importance of fostering a 
the burden of showing that her work provides social benefit through criticism of the original work. ${ }^{210}$ Once the parodist shows some social benefit and criticism from the use of the author's work, however, the burden should shift to the original author to explore the reasons behind the refusal to transact. ${ }^{211}$ Allocating the burden in this manner respects the original author's control over the preparation of derivative works by requiring her to produce evidence only against a recognized parodist. ${ }^{212}$

As explained by Professor Gordon, an author who refuses to transact merely to avoid ridicule effectively prevents much needed information, namely in the form of critical commentary, from reaching the market. ${ }^{213}$ Further, it is suggested that an author may have antidissemination motives not only due to an unwillingness to face ridicule, but also due to potential disagreement with the critical commentary made by the parodist. ${ }^{214}$ For an author who likely would refuse to license for such a reason, the nature of the transaction should weigh in favor of fair use. ${ }^{215}$ This determination may be aided by the second factor, the strength of the critical element; that is, the more effective

reasonable market transaction, as stressed by Merges and Gordon in the models above. See supra text accompanying notes 172-76, 188-89 (describing the significance of considering the nature of the market transaction, as applied in the Merges and Gordon models). This factor also adopts the reasoning suggested by Professor Winslow regarding the importance of the conduct and relations of the parties and the strength of the parodic element. See supra note 198 and accompanying text (suggesting that the likelihood of voluntary exchange depends greatly on "the relationship between the parties and the reasons the original author wants to retain the interest").

${ }_{210}$ See Gordon, supra note 24 , at 1625 (asserting that if a parodist's use "serves no social purpose, ... further consideration of his fair use claim would be unwarranted").

${ }_{211}$ Requiring the original author to provide evidence minimizes information problems. For an example of constraints that the lack of information may place on an economic analysis of the fair use defense, see Fisher, supra note 107, at 1739. See also supra notes 159-63 (discussing how works of parody weaken the efficiency argument in favor of allocating the right of derivative uses to an original author); supra note 206 (discussing Gordon's recognition of the possibility of burden-shifting to the original author if the defendant provides proof of market failure).

${ }^{212}$ See supra notes 134-48 and accompanying text (exploring the most efficient allocation of the right to produce derivative works between the original and derivative authors).

${ }^{213}$ See supra text accompanying notes 175-76 (discussing the anti-dissemination motives of authors who desire to keep information from the public).

${ }^{214}$ See Merges, supra note 107, at 311-12 (discussing the problems with Posner's weapon/target distinction).

${ }^{215}$ Although this effectively may serve as a deterrent to the creation of original works, "the free flow of information is at stake." Gordon, supra note 24, at 1633 . Because the goal of copyright is to provide incentives for the creation of works that satisfy consumer tastes, "[i]f a criticism reveals a work's flaws, it is appropriate that demand for the work should decrease." Id. 
the critical message in the parody, the more likely an illegitimate motive fuels the original author's desire to deny the derivative use. If the strength of the parodic element is weak, however, the desire of an original author to maintain control over her work should be respected, and the nature of the transaction should weigh against fair use. ${ }^{216}$

An inquiry into the nature of the transaction acts as an incentive for authors to transact. Most parodists, aware that failing to offer reasonable compensation before using a work weakens the defense of fair use, likely will attempt to transact with an original author. Most authors, aware that refusing to transact with parodists for purposes of withholding criticism from the public will strip them of their rights, likely will negotiate with parodists ex ante. The first prong, then, may lead to increases in voluntary transactions, which achieves a movement toward an efficient state. ${ }^{217}$ The focus on the parties' mutual willingness to license also injects an element of objectivity into the fair use analysis that is otherwise lacking. ${ }^{218}$

\section{b. The Strength of the Critical Element}

This factor requires a determination of the extent to which the derivative work provides a critical message. The purpose of this factor is two-fold: to examine the strength of the externalities, ${ }^{219}$ and to address the issue of market substitution. ${ }^{220}$ The inquiry into the strength of the critical element, however, does not embrace the Campbell distinction between works of parody and satire, or Judge Posner's target/weapon distinction, for two reasons. ${ }^{221}$ First, as many works serve

${ }^{216}$ See id. at 1633-34 ("Market failure should be found only when the defendant can prove that the copyright owner would refuse to license out of a desire unrelated to the goals of copyright-notably, a desire to keep certain information from the public.").

${ }^{217}$ See supra notes 111-13 and accompanying text (explaining that many efficient solutions may be reached by voluntary transactions between parties under perfect market conditions).

${ }^{218}$ See supra text accompanying notes 188-90 (recounting Professor Merges's theory that a market transaction focus looks to net profit as opposed to a determination of whether a work may be characterized as parody or satire).

${ }^{219}$ See supra note 160 and accompanying text (defining externalities).

220 See supra note 95 (defining market substitution). This factor is also referenced by the first factor, the nature of the transaction, to determine the legitimacy of an original author's motive in denying a derivative use. See supra notes 214-16 and accompanying text (discussing how the strength of the critical element helps determine the author's motives in refusing to license).

${ }^{221}$ See supra notes 82-84 (discussing the Campbell test for a work to qualify as a parody as distinguished from satire). The Supreme Court recognized that a work that 
dual purposes of attacking both the original and society as a whole, categorizing according to one or the other may be impossible. ${ }^{222} \mathrm{Re}-$ quiring that each court create a bright-line as to the sufficient level of critical commentary directed towards an original to qualify as a parody risks inconsistency in decisions. ${ }^{223}$ Second, a derivative work that qualifies as a satire may provide higher social value than a parody since it criticizes far more than just one work. ${ }^{224}$ Thus, it is not altogether clear that works qualifying as satire necessarily should enjoy lesser weight in the fair use inquiry. ${ }^{225}$ Rather than relying on categorizations, this factor applies a sliding-scale approach: the greater the critical message, the more the derivative work deserves fair use protection.

Weighing the strength of the critical message incorporates Campbell's evaluation of the "transformative" value of a derivative work; ${ }^{226}$ that is, the more a derivative work provides "new information, new

loosely targets an original still may be sufficiently aimed at the original to qualify as a parody. See Campbell v. Acuff-Rose Music, Inc., 510 U.S. 569, 580-81 n.14 (1994). Because a work may contain "both parodic and non-parodic elements," the Court broadly required that a parody reasonably "be perceived as commenting on the original or criticizing it, to some degree." Id. at 581, 583. However, in a concurring opinion, Justice Kennedy opted for a narrower test, stating that "[t] he parody must target the original, and not just its general style." Id. at 597 (Kennedy, J., concurring); see also supra notes $178-80$ and accompanying text (describing Judge Posner's target/weapon distinction).

${ }^{222}$ See Campbell, 510 U.S. at 581 (discussing the difficulty in drawing a distinctivn between a parody and a satire, especially when elements of both exist); Merges, supra note 107, at 311 (noting that "a successful parody might often be expected to parody both a copyrighted work and the values it represents").

${ }^{223}$ See supra note 102 and accompanying text (discussing criticisms of the Ninth Circuit's decision in Dr. Seuss Enters. v. Penguin Books, Inc., 109 F.3d 1394 (9th Cir. 1997), as a narrow construction of the Campbell decision).

${ }^{224}$ See Merges, supra note 107, at 311-12 (stating that the "weapon" cases "serve the goal of promoting criticism of and commentary on 'larger' social issues and values").

${ }_{225}$ In Campbell, the Supreme Court recognized that, in the right circumstances, fair use protection may extend to works of satire. The Court stated:

[W] hen there is little or no risk of market substitution, whether because of the large extent of transformation of the earlier work, the new work's minimal distribution in the market, the small extent to which it borrows from an original, or other factors, taking parodic aim at an original is a less critical factor in the analysis, and the looser forms of parody may be found to be fair use, as may satire with lesser justification for the borrowing than would otherwise be required.

Campbell, 510 U.S. at 581 n.14; see also Gregory K. Jung, Dr. Seuss Enterprises v. Penguin Books, 13 BERKELEY TECH. L.J. 119, 132 (1998) (arguing that "[t]he "market failure theory applies just as well to satires as parodies").

${ }^{226}$ See supra notes 79-81 and accompanying text (discussing the importance of the transformative nature of copyrighted works in providing social benefit); supra notes 159-63 and accompanying text (discussing the positive externality of public benefit). 
aesthetics, new insights and understandings" in the form of criticism, the more valuable it is to society. ${ }^{227}$ Economically, a copyright owner is unlikely to internalize the positive externalities that arise from the creation and dissemination of a derivative work and, as a result, may refuse to transact even in a situation where the aggregate social benefit increases. ${ }^{228}$ Thus, to achieve efficiency, the transformative value provided by the critical message must be considered in determining the desirability of reallocation.

The critical impact of the work also increases with the fame of the ridiculed work. Although parodies "almost invariably copy publicly known, expressive works, ${ }^{, 229}$ the increase in public benefit associated with the chosen target of the criticism should not be overlooked. A work created solely for private commercial gain, however, may not serve the public as well as a work created primarily to provide a critical message. ${ }^{230}$ Yet, because activities of comment and criticism "are generally conducted for profit in this country, ${ }^{231}$ this consideration should be given minimal weight in the inquiry. ${ }^{232}$

Finally, the strength of the critical element addresses the extent to which the work serves as a market substitute for the original. ${ }^{233}$ As a

${ }_{227}^{22}$ Leval, supra note 1, at 1111.

${ }^{228}$ The movement is towards a Kaldor-Hicks efficient state, rather than a Pareto efficient state. See supra note 109 (defining Pareto efficiency and Kaldor-Hicks efficiency). That is, it does not argue that reallocation necessarily will make the copyright owner better off.

${ }^{229}$ Campbell, 510 U.S. at 586.

${ }^{220}$ Section 107 directs a court to consider whether the character of the use is of a commercial nature or is for a nonprofit educational purpose. See 17 U.S.C. $\$ 107(1)$ (1994); see also, e.g., MCA, Inc. v. Wilson, 677 F.2d 180, 182 (2d Cir. 1981) (considering whether the use "was primarily for public benefit or for private commercial gain").

${ }^{231}$ Campbell, 510 U.S. at 584 (citing Harper \& Row, Publishers, Inc., v. Nation Enters., 471 U.S. 539, 592 (1985) (Brennan, J., dissenting)).

${ }^{292}$ For a discussion of pre-Campbell reactions to a commercial motive within the lower courts, see supra notes 55-58 and accompanying text. The Court in Campbell determined that a commercial use is not presumptively unfair and should be limited to one factor in the fair use inquiry. See Campbell, 510 U.S. at 584 (“[C]ommercial or nonprofit educational purpose of a work is only one element of the first factor enquiry into its purpose and character.").

${ }^{293}$ The factor, however, should avoid the requirement addressed in Campbell, that a parodist demonstrate an absence of harm to nonparodic derivatives in markets related to that of the parody. See Campbell, 510 U.S. at 593 ("Evidence of substantial harm to [the derivative market] would weigh against a finding of fair use, because the licensing of derivatives is an important economic incentive to the creation of originals."). I agree with Professor Winslow, who points out that it asks too much of parodists to demonstrate an absence of harm to works within markets that do not even compete with the original. See Winslow, supra note 55, at 823 ("It is illogical ... to include critical derivative works, when an author probably will not license, in the same market as 
work increases in critical purpose, the work becomes more likely to serve a different audience. As a result, a heavily critical parody likely will not compete with, or act as a substitute in, the market for the original. $^{234}$ Therefore, to address sufficiently the strength of the externalities and the issue of market substitution, an increase in the critical element must weigh in favor of fair use.

\section{c. The Amount of Creative Contributions}

Finally, an increase in the amount of contribution by the parodist should weigh in favor of finding fair use. The purpose of this prong is to minimize the free-rider problem ${ }^{235}$ and to assess whether the parodist deserves the allocation of the right to prepare a derivative work. ${ }^{236}$ Evaluating the parodist's contributions minimizes the free-rider problem by ensuring that the parodist does not use the original author's creativity at no cost. A mere devotion of extensive resources to the parody, however, should not alone favor a finding of fair use. ${ }^{237}$ Rather, only those creative elements added by the parodist should determine whether the contributions sufficiently overcome the free-rider problem. ${ }^{238}$ In addition, the greater the parodist's own creative contributions, the greater the value society places on that work. Thus, an

noncritical derivative works, which the author may license."); see also Leibovitz v. Paramount Pictures Corp., 137 F.3d 109, 116 n.6 (2d Cir. 1998) (suggesting that a defendant is not required to demonstrate an absence of market harm to a derivative market where the plaintiff cannot identify any derivative market that may be harmed).

${ }^{234}$ The Court in Campbell recognized that "the parody and the original usually serve different market functions." 510 U.S. at 591 (citations omitted).

${ }^{235}$ See supra text accompanying notes 117-22 (discussing the free-rider problem).

${ }^{236}$ See supra text accompanying notes 152-66 (discussing why arguments in favor of granting an original author control over the derivative uses of her work may be strained for works of parody). This factor addresses the substantiality of the taking in traditional fair use analysis. See Campbell, 510 U.S. at 587-88 (" [A] work composed primarily of an original, particularly its heart, with little added or changed, is more likely to be a merely superseding use, fulfilling demand for the original."). This prong also parallels the third factor of Professor Winslow's model. See Winslow, supra note 55, at 811-12 (recommending a requirement that the parodist make substantial adaptations or contributions to the original work).

${ }^{237}$ See Feist Publications, Inc. v. Rural Tel. Serv. Co., 499 U.S. 340, 349 (1991) (finding that the "primary objective of copyright is not to reward the labor of authors, but "to promote the "Progress of Science and useful Arts"' (citation omitted)); L. Batlin \& Son, Inc. v. Snyder, 536 F.2d 486, 492 (2d Cir. 1976) (en banc) ("To extend copyrightability to miniscule variations would simply put a weapon for harassment in the hands of mischievous copiers intent on appropriating and monopolizing public domain work.").

${ }^{238}$ See supra notes $26-30$ (discussing the differences required between an original work and derivative works to make the derivative work copyrightable). 
increase in the substantiality of the contributions by the parodist weighs in favor of fair use.

\section{Limitations}

Certainly, the proposed model is not without limitations. The most obvious drawback is that the model requires the case-by-case application of a number of factors. Despite the model's avoidance of a threshold characterization, and the addition of an element of objectivity (through the first factor), the weight given to each factor requires subjective assessments. Additionally, because the model contains few, if any, measurable variables, the value given to each factor likely will differ among factfinders. ${ }^{239}$ Any such weighing and balancing of subjectively valued elements may lead to inconsistent results. The application of the proposed model to the Leibovitz decision exposes these limitations.

\section{APPLICATION OF THE PROPOSED MODEL TO LEIBOVTTZ V. PARAMOUNT PICTURES}

\section{A. The Second Circuit's Decision}

In Leibovitz, the Second Circuit faced the question of whether the District Court erred in holding that the use of a parody of Leibovitz's photograph by Paramount was fair. ${ }^{240}$ Leibovitz contended that even if the advertisement appropriately was considered a parody of her photograph, Paramount used it for commercial purposes and replicated more of her work than necessary. ${ }^{241}$ The Second Circuit started its analysis with a brief history of the fair use defense and a discussion

${ }^{239}$ Professor Lloyd Weinreb noted this problem in a recent commentary on fair use where he disagreed with the economic approaches of Professors Fisher and Gordon in that "fair use depends on a calculus of incommensurables." Lloyd L. Weinreb, Fair Use Lecture (Nov. 12, 1988), in 67 FORDHAM L. REV. 1291, 1306 (1999). Weinreb argued that although some elements of the fair use test give the "comforting appearance of being measurable ... the appearance is empty." Id. at 1307.

${ }^{40}$ See Leibovitz v. Paramount Pictures Corp., 137 F.3d 109, 110 (2d Cir. 1998). The district court found that " $[t]$ hree of the four fair use factors in the present case militate in favor of a finding of fair use, largely because the defendant's transformation of the plaintiff's photograph has resulted in public access to two distinct works." Leibovitz v. Paramount Pictures Corp., 948 F. Supp. 1214, 1226 (S.D.N.Y. 1996). Furthermore, Leibovitz herself stated in her deposition that she thought the Nielsen picture was a parody of her own work, and the court subsequently found that the Nielsen photograph was a parody rather than a satire. See id. at 1222-23.

${ }^{241}$ See Leibovitz, 137 F.3d at 112. 
of the Supreme Court's decision in Campbell. ${ }^{242}$ In doing so, it clarified both the general fair use defense and the fair use defense for parodies. $^{243}$ The court then applied the four factors of section 107 to Paramount's advertisement. ${ }^{244}$

Considering the purpose of the use, the court first questioned whether "Paramount's advertisement 'may reasonably be perceived' ... as a new work that 'at least in part, comments on' Leibovitz's photograph." 245 The court quickly decided that Paramount's additions to the original were sufficient to create a "transformative work." ${ }^{246}$ After briefly noting the closeness of the inquiry, the court also found that the advertisement adequately commented on the seriousness and pretentiousness of the original, thereby achieving the level of ridicule contemplated by Campbell. ${ }^{247}$ Furthermore, the court noted that the advertisement might reasonably be perceived to comment on the Leibovitz photograph by "extol[ling] the beauty of the pregnant female body, and, rather unchivalrously... disagree[ing] with this message. ${ }^{248}$ Thus, the court found a parodic purpose for the defendant's advertisement.

In addressing the commercial purpose of the advertisement, the court opined that, although the advertising use lessened the "indulgence" to which the ad was entitled, “'[1]ess indulgence' ... does not mean no indulgence at all." ${ }^{249}$ The court found that "the strong parodic nature of the ad tip[ped] the first factor significantly toward fair use. $^{\text {n250 }}$

Under the guidance of Campbell, the court determined that the

${ }^{242}$ See id. (citing Campbell v. Acuff-Rose Music, Inc., 510 U.S. 569, 577-78 (1994)).

${ }^{243}$ See id. at 112-15; supra notes 72-97 and accompanying text (discussing the Supreme Court's application of the fair use defense in Campbell).

${ }^{244}$ See id. at 114.

${ }^{245}$ Id. (quoting Campbell, 510 U.S. at 580,582 ).

246 Id. The court noted "some concern about the ease with which every parodist could win" by pointing out the differences between their works and the original. Id. The court then stated that "[b]eing different from an original does not inevitably 'comment' on the original." Id.

${ }^{247}$ See id. (finding that "[b]ecause the smirking face of Nielsen contrasts so strikingly with the serious expression on the face of Moore, the ad may reasonably be perceived as commenting on ... the original").

248 Id. at 115 (footnote omitted).

249 Id. (quoting Campbell, 510 U.S. at 585). The court also considered whether the jocular nature of the film advertised could be extended to a consideration of the advertisement itself and found that "the parodic comment of the ad might reasonably be perceived as reenforced [sic] by the kidding comments of the movie concerning pregnancy and parenthood." Id.

${ }^{250} \mathrm{Id}$. 
second factor, the nature of the copyrighted work, slightly favored Leibovitz. $^{251}$ The court nonetheless diligently followed the Supreme Court's instruction, stating that "the creative nature of an original normally will not provide much help in determining whether a parody of the original is fair use. ${ }^{252}$

In considering the third factor, the substantiality of the portion used by Paramount, the court observed that Paramount went to "great lengths" to copy the protectable aspects of the original. ${ }^{253}$ The protectable artistic elements that Paramount copied included the particular lighting, camera angle selection, and resulting skin tone of the subject. ${ }^{254}$ As a result, the court found that Paramount took more of Leibovitz's photograph than minimally necessary to conjure up the original. $^{255}$ The court refused, however, to allow the third factor to tip the scale in favor of Leibovitz, reasoning that the "approach [in Campbell] leaves the third factor with little, if any, weight against fair use so long as the first and fourth factors favor the parodist."256

Finally, as to the fourth factor, the court found that Paramount's photograph "did not interfere with any potential market for [Leibovitz's] photograph or for derivative works based upon it. ${ }^{257}$ Leibovitz repeatedly stated in a deposition, however, that the parody would have a negative effect on her relationship with other celebrities whom she photographs, as a result of their fear of future ridicule or embarrassment. $^{258}$ In response, the court noted that the "possibility of criticism or comment-whether or not parodic-is a risk artists and their subjects must accept. ${ }^{259}$ Thus, the court concluded that the aggregate

${ }^{251}$ See id. (stating that Paramount conceded the point that Leibovitz's photograph exhibited creative expression).

${ }^{252}$ Id:; see also supra notes 87-88 and accompanying text (summarizing the Campbell decision concerning the second factor).

${ }^{253} I d$. at 116.

${ }^{254}$ See id. ("Elements of originality in a photograph may include posing the subjects, lighting, angle, selection of film and camera, evoking the desired expression, and almost any other variant involved." (quoting Rogers v. Koons, 960 F.2d 301, 307 (2d Cir. 1992))).

${ }^{255}$ See id. (explaining that Paramount copied the protectable aspects of Leibovitz's photograph to an "extreme degree"). The court also noted that Paramount used computer enhancements to ensure an almost identical skin color as on the subject of the original. See id.

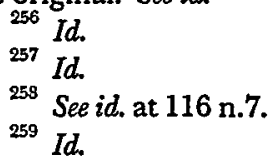


assessment of the factors strongly favored the defendant and affirmed the District Court's ruling of summary judgment for Paramount. ${ }^{260}$

\section{B. Applying the Economic Model to the Facts of Leibovitz}

Application of the proposed model to the facts of Leibovitz leads to a different result than that reached by the Second Circuit. The first factor, the nature of the transaction, weighs squarely against fair use because Paramount never attempted to transact with Leibovitz. ${ }^{261}$ The purpose of the first prong is to promote voluntary transactions, and Paramount would fail the initial burden of proving an attempted transaction. ${ }^{262}$

Next, the model requires an evaluation of the strength of the critical element. The public benefit from Paramount's work weighs in favor of fair use. Certainly, as the Second Circuit found, the work is transformative, ${ }^{26 s}$ because the advertisement reasonably provides a number of critiques of the underlying work. ${ }^{264}$ The external benefit also is enhanced by the popularity of the Leibovitz work and the reach of the Paramount advertisement. Moreover, the critical element suggests minimal harm to the market for the original since Paramount's work is likely to cater to a different audience. The commercial purpose of the work, however, dilutes the weight given to this factor. The work was not created for the sale of parody for its own sake, but rather for the purpose of promoting a commercial product. ${ }^{265}$

Finally, the third factor, the adaptations made by Paramount,

${ }^{260}$ See id. at 117 (finding that the aggregate assessment might be more difficult in a case where the factors weighed "heavily on opposite sides of the balance").

261 See Leibovitz v. Paramount Pictures Corp., 948 F. Supp. 1214, 1216 (S.D.N.Y. 1999) (finding that Paramount never attempted negotiations with Leibovitz).

${ }^{262}$ Assuming Paramount attempted to transact and demonstrated some level of criticism of Leibovitz's work, Paramount's argument as to the nature of the transaction would be strong. The record suggests that Leibovitz likely would have refused to license the work for fear that future celebrities would avoid her services for fear of being parodied. See supra note 258 and accompanying text (explaining that Leibovitz believed the parody would hurt her relationships with celebrities who feared future embarrassment if photographed by her). Additionally, Paramount's ad presented critical elements, which further suggests that Leibovitz would have refused to transact for antidissemination purposes.

${ }^{263}$ See Leibovits, 137 F.3d at 114 ("Plainly, the ad adds something new and qualifies as a 'transformative' work.").

${ }^{264}$ See id. at 114-15 (describing the number of possible critiques conveyed by the image of Leslie Nielsen's head on the pregnant body of Demi Moore).

${ }^{265}$ See id. at 115 (explaining that "[ $\left.\mathrm{t}\right]$ he ad was created and displayed to promote a commercial product, the film"). 
weighs heavily against fair use. The minimal creative contributions made by Paramount are insufficient to overcome the free-rider problem. Although Paramount devoted extensive resources to ensure similarity between the works, Paramount acquired most of the creative elements from Leibovitz free of cost. ${ }^{266}$ In addition, the minimal contributions do not support a claim by Paramount for an allocation of the derivative use. Therefore, the third factor weighs against a finding of fair use.

On balance, the final assessment under the proposed model is difficult given the strength of the factors on both sides. The proposed model, however, supports a finding against fair use. In comparing my conclusion with that of the Second Circuit, the former emphasizes an optimal economic outcome whereas the latter follows the judicial precedent of Campbell. Although the Second Circuit's outcome was legally appropriate, it falls short when economic considerations are taken fully into account. Considering the three factors of the proposed economic model, the Second Circuit adequately addressed only the strength of the critical element. The Second Circuit did not address Paramount's failure to attempt a transaction and it appears that the court trivialized the free-rider problem. By relying too heavily upon the overriding parodic purpose and the minimal market harm to the original, the court failed to accord sufficient weight to the minimalness of Paramount's contributions and the extensiveness of its copying.

\section{CONCLUSION}

The fair use defense provides flexibility to ensure that its dual aims-to provide incentive for authors to produce creative works and to promote the adequate dissemination of such works-are met. Courts have struggled with the fair use defense for centuries, especially when dealing with works of parody. Uncertainty exists even after the Supreme Court's decision in Campbell v. Acuff-Rose Music, Inc., in which the Court attempted to clarify the fair use defense for works of parody. In that case, the Court directed lower courts to make a variety of subjective evaluations, including whether a work qualifies as a parody or a satire. As scholars have recognized, economics should guide courts in analyzing the fair use defense in parody cases because every

${ }^{266}$ See id. at 116 (finding that Leibovitz's protectable creativity extends to "such artistic elements as the particular lighting, the resulting skin tone of the subject, and the camera angle"). 
fair use analysis requires an exploration into the fundamental tenets of copyright law which, in turn, are based on economic principles.

Based on the economic principles of copyright law and a survey of economic models created by scholars, I propose a model to apply to fair use cases addressing works of parody. The factors of the model are: (1) the nature of the transaction, (2) the strength of the critical element, and (3) the amount of creative contributions. This model provides a method of evaluation that addresses economic concerns while maintaining a practical, case-by-case inquiry. The model avoids the determination discussed in Campbell of whether a work qualifies as a parody or a satire, since courts may overemphasize the distinction. The model is limited, however, by requiring subjective assessments regarding the weight given to each factor.

Application of the proposed economic model to the Second Circuit's decision in Leibovitz v. Paramount Pictures Corp., in which the court decided that the use of a copyrighted photograph of pregnant actress Demi Moore constituted fair use, reveals that the Second Circuit adequately addressed the strength of the critical message. The proposed model requires a more extensive exploration, however, into the reasons for the failure of the transaction. In addition, Leibovitz's interest in protecting against free-riders should have been given more weight. I conclude that the economic model favors a finding against fair use. 